\title{
アスベスト含有廃棄物の低温加熱溶融処理 に関する基礎的研究
}

\author{
内野 英宏 1 坂本 佳次郎 2 府内 洋一 3 ・中村 秀明 4 ・宮本 文穂 5 \\ 1正会員（株）富士ピー・エス＼cjkstart技術製造本部（テ105-0004 東京都港区新橋4-24-8） \\ E-mail:uchino@fujips.co.jp \\ 2 (株) ストリートデザイン 代表取締役（テ211-0041 神奈川県川崎市中原区下小田中6-9-30) \\ E-mail:k.sakamoto@street-design.co.jp \\ 3 (株) 富士ピー・エス 土木本部（广810-0073 福岡市中央区舞鶴2-2-11） \\ E-mail:funai@fujips.co.jp \\ 4正会員 山口大学准教授 理工学研究科環境共生系専攻（干755-8611 宇部市常盤台2-16-1） \\ E-mail:nakahide@yamaguchi-u.ac.jp \\ 5フェロー会員 山口大学教授 理工学研究科 環境共生系専攻（干755-8611 宇部市常盤台2-16-1） \\ E-mail:miya818@yamaguchi-u.ac.jp
}

\begin{abstract}
アスベストによる健康被害が大きな社会問題となっている中，その飛散防止対策が喫緊の課題となって いる．特に，これからピークを迎える建築物の改修・解体に伴い発生するアスベスト含有廃棄物の適正処 理の確保が極めて重要である。本研究は, アスベスト含有廃棄物の処理に関して, 吹付けアスベストの除 去および封じ込め工事に用いる薬液を添加，加熱することでアスベストの無害化（非繊維化，非石綿化） を試みた。アアスベストは，カルシウム化合物を主成分とする薬液と混合し， $700^{\circ} \mathrm{C}$ 低温で加熱すること で, 結晶構造が崩壊して非繊維化, 非石綿化が可能であることがわかった。 また, 現場の吹付けアスベス トやアスベスト成形板に対しても，同様の効果を確認することができた．
\end{abstract}

Key Words : asbestos, waste matter, sprayed asbestos, chrysotile asbestos, melting, calcium

\section{1.はじめに}

アスベスト（石綿）は人体内に吸い込むと肺ガンや中 皮腫などの呼吸器系疾患を引き起こすため, その健康被 害が大きな社会問題になっている(1). アイスベストは, 天然に存在するケイ酸塩の繊維状鉱物で，蛇紋石系のク リソタイル (白石綿) ，角閃石系のクロシドライト（青 石綿) とアモサイト (茶石綿) などがある. 安価な上, 而火性, 而熱性, 電気絶縁性, 而摩耗性, 化学的安定性 を示すことから，建設資材をはじめ，広範多岐に使用さ れている.土木・建築分野では，主に建築用の耐火被覆 材や建材として使用されているが，一部道路施設等にも 使われており ${ }^{5}$, 今後, 建築物や施設の老朽化による改 築や解体の増加に伴って，アスベストを含有する廃棄物 が多量に排出されることが予想される.

2004年10月1日から一部の限られた用途以外の輸入, 製造などが労働安全衛生法・同施行令によって禁止され たが，2004年までの我が国におけるアスベスト輸入量の 合計はおよそ 1,000 万レンも及び，その9割が建設材料 として使用されてきた。国土交通省の資料のよると我
が国のアスベストの輸入量は，1970年代から1990年代に 掛けてがピークであり，この時期には，年間30万トンの アスベストが輸入されている．これらの大部分は，建材 に使用されており，今後，これらの建材を使った建造物 は，解体やリフォームされるが，そのピークは，2020年 〜2040年頃になると予想されており, その処理が喫緊の 課題となっている.

アスベストは，シリカ $\left(\mathrm{SiO}_{2}\right)$ とマグネシウム $(\mathrm{Mg})$ 元素 が結びついた䋊維状のシリカ化合物であり，アスベスト そのものには，化学的な毒性はない.アスベストが有害 物質とされるのは，空気中に浮遊しやすいアスベスト繊 維を人が吸入すると，その結晶構造が針状であるため, 肺から排出されにくく, 肺の組織に蓄積されるためであ る. その結果, 肺ガン, 中皮腫などの呼吸器系の疾患が 発生する. シリカとマグネシウムの結合を切り離せば, 別の結晶構造となり, 無害化 (本研究での無害化とは, 非繊維化，非石綿化を意味する）が可能となる.このよ うな処理としては，溶融による処理があるが，溶融には $1,500^{\circ} \mathrm{C}$ もの高温が必要になり, 焼却施設の不足, 処理 コストが掛かるなどの問題を抱えている. 
表-1 実験用試料

\begin{tabular}{|c|c|c|c|}
\hline & クリソタイル & アモサイト & クロシドライト \\
\hline 含有率 & $95 \%$ & $99 \%$ & $99 \%$ \\
\hline 分類 & 蛇紋石系 & 角閃石系 & 角閃石系 \\
\hline 化学式 & $\mathrm{Mg}_{3} \mathrm{Si}_{2} \mathrm{O}_{5}(\mathrm{OH})_{4}$ & $(\mathrm{Fe}, \mathrm{Mg})\left(\mathrm{Si}_{8} \mathrm{O}_{22}\right)(\mathrm{OH})_{2}$ & $\mathrm{Na}_{2} \mathrm{Fe}_{3}{ }^{2+} \mathrm{Fe}_{2}{ }^{3+}\left(\mathrm{Si}_{8} \mathrm{O}_{22}\right)\left(\mathrm{OH}_{2}\right.$ \\
\hline 物理的状態 & 繊維 $($ 単斜晶系 $)$ & 繊維 $($ 単斜晶系 $)$ & 䋊維 $($ 単斜晶系 $)$ \\
\hline 比重 & 2.55 & 3.43 & 3.37 \\
\hline 融点 & $1,521^{\circ} \mathrm{C}$ & $1,399^{\circ} \mathrm{C}$ & $1,193^{\circ} \mathrm{C}$ \\
\hline
\end{tabular}

表-2 使用した薬液

\begin{tabular}{|c|c|c|c|}
\hline 薬液 & 主成分 & カルシウム化合物含有率 & 備考 \\
\hline $\mathrm{R}$ 剤 & カルシウム化合物 & $35 \mathrm{w} \%$ & アスベスト除去用 \\
\hline $\mathrm{P}$ 剂 & カルシ着力 : 弱) \\
\hline
\end{tabular}

このような中，小島らは，アスベストにフロン分解物 を加えることにより，従来より低温（600～700 C $）$ で無 害化できる技術の研究開発を行っているが1).さらに, 小島らは，塩化物を使った低温無害化の研究も行ってい $3^{12) \sim 16)}$

現在，回収されたアスベストのほとんどは，埋め立て 処理されているが，アスベスト含有廃棄物は，特定管理 物質に指定されており，飛散などのリスクがあるため㛜 重な管理下で行う必要がある。しかし，アスベスト含有 廃金物を受け入れる最終処分場の許容量が全国的に見て も限られており，これから先のアスベスト含有建築材等 の廃棄量がピークを迎えるにあたり，処分場の枯渇や処 分料の高騰などが，不法投棄や違法処理の要因となるこ とが懸念される.

このような状況下，アスベスト含有廃莗物の無害化， さらには資源としての有効利用に関する研究は急務であ り，現在多くの民間企業や公的研究機関で数々の取り組 みが行われているが17，いまだ低コスト・低エネルギー で安全に大量処理できる画期的な処理技術は開発されて いない

著者らは，アスベスト対策の除去および封じ込め工事 に使用する薬液が含浸されたアスベスト含有廃棄物が, $700^{\circ} \mathrm{C}$ で加熱されることにより無害化できることを確認 した．この基礎的な技術については，すでに小島らが特 許を取得している. 小島らの研究では，フロン分解物お よび塩化物を用いているが，著者らは実際の工事で使用 するカルシウム化合物を含む薬液を用いることにより， 実験室レベルではなく，実用レベルでの低温無害化を目 的としている. 併せて, これまで研究事例の少なかった クロシドライトやアモサイトについても検討を行った.

\section{2. アスベスト含有廃棄物}

アスベストは，主に6つの種類がある。 クリソタイル (白石綿) , クロシドライト（青石綿），アモサイト
(茶石綿)，アンソフィライト，トレモライトおよびア クチノライトである。このうち，日本で主に使用されて いるのは，前3者であり，いずれも䋊維状で，引張力が 強く, 而熱性, 絶縁性, 而薬品性, 而腐食性, 而摩耗性 に優れることから，保温材，吹付け材，建材，水道管， クラッチ・ブレーキなどに使用されてきた. そして，ア スベストを含有した建設廃棄物は，使用形態により主に 次の3つに大別される.

1) 吹付けアスベスト

2) アスベスト保温材

3) アスベスト成形板

この中で，撤去・処分過程でアスベストが飛散しやす いのは吹付けアスベストおよびアスベスト保温材である。 しかし，アスベスト成形板もセメントの風化や破砕によ るアスベストの露出や飛散など，廃棄物としての安全性 の問題が指摘されている.これらに含まれるアスベスト 含有率は，吹付け材では約5～70\%，保温材では約 $1.5 〜$ 50\%，成形板（スレート）では10～20\%である.

\section{3. アスベスト標準試料の加熱溶融実験}

はじめにでも述べたとおり，アスベストを無害化する には， $1,500^{\circ} \mathrm{C}$ 以上の高温で焼却処理する必要があるが， 焼却施設の不足，処理コストの問題がある。そこで，本 研究では都市清掃工場のエネルギーで達成可能な, $700^{\circ} \mathrm{C}$ 程度の低温で焼却することを念頭に加熱無害化実 験を行った.

\section{(1) 実験概要}

本研究では，まず始めにアスベストそのものに対して 薬液による低温無害化の効果を確かめるため，アスベス 卜標準試料を用いて加熱溶融実験を行った．アスベスト 試料は，(社)日本作業環境測定協会が販売している3種 類の石綿分析用標準試料を使用した。実験に用いた試料 の概要を表-1に示す．クリソタイルは，米国California州 


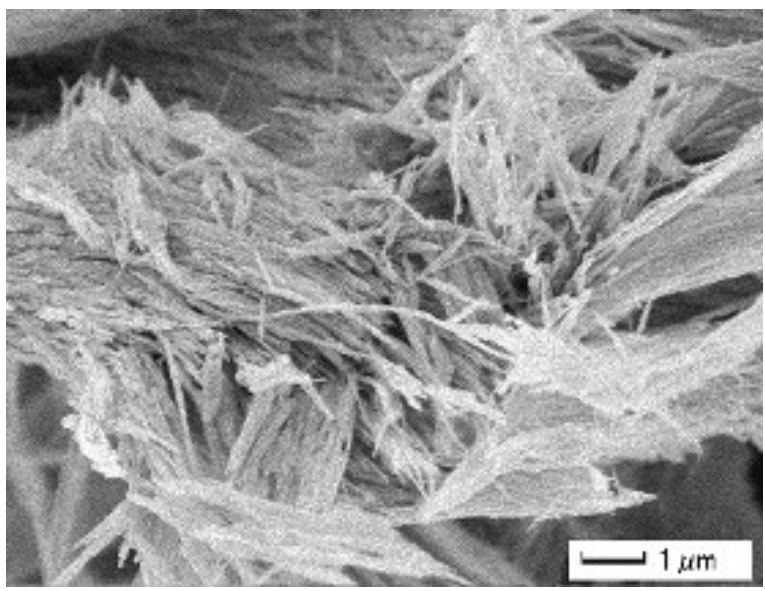

クリソタイル $(\times 10,000$ 倍 $)$

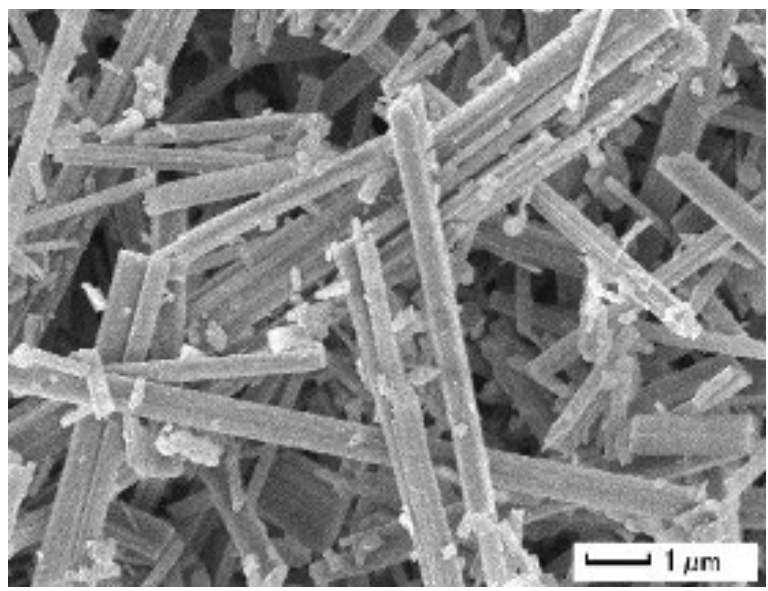

アモサイト $(\times 10,000$ 倍 $)$

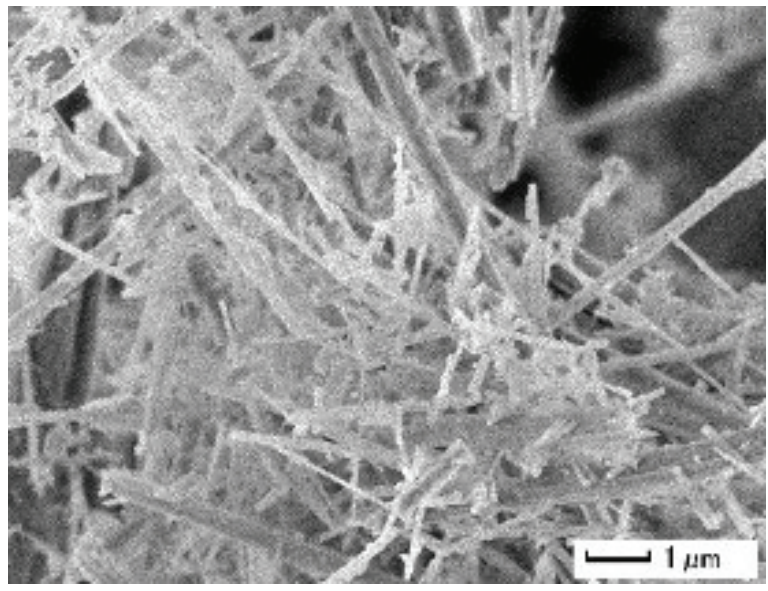

クロシドライト $(\times 10,000$ 倍 $)$

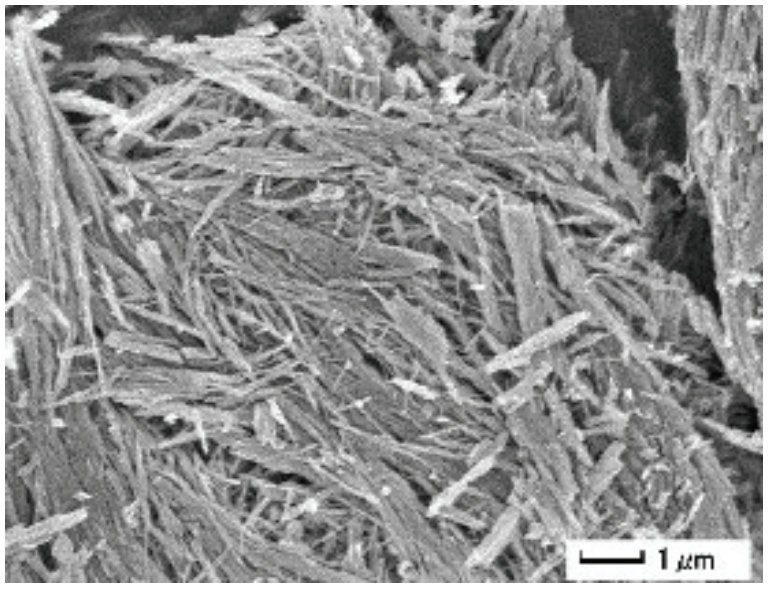

クリソタイル $1,000^{\circ} \mathrm{C} 2$ 時間 $(\times 10,000$ 倍 $)$

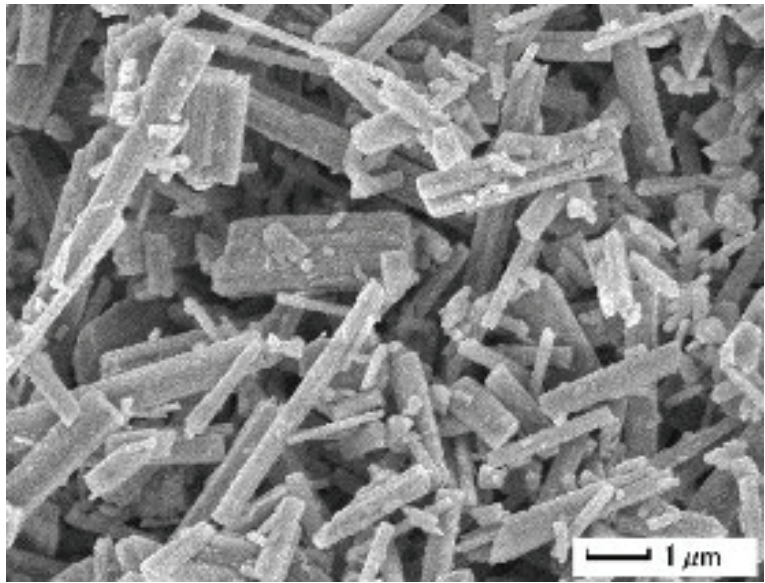

アモサイト $1,000^{\circ} \mathrm{C} 2$ 時間（×10,000倍 $)$

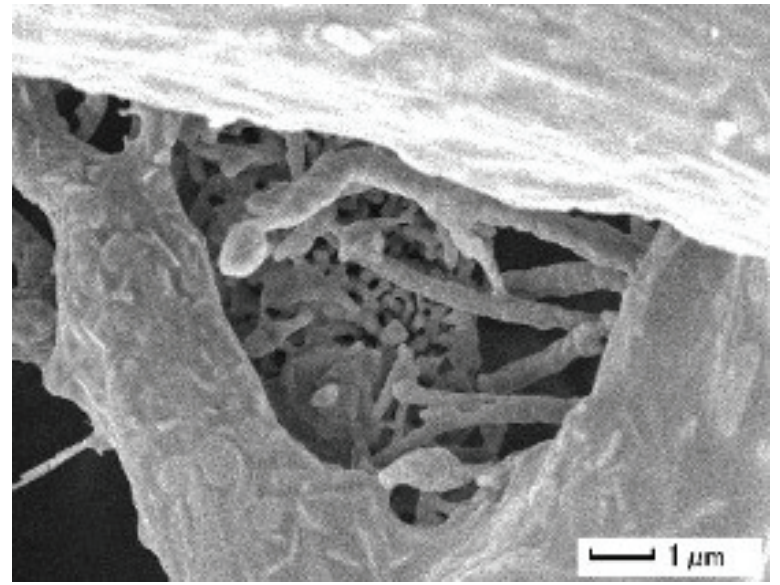

クロシドライト $1,000^{\circ} \mathrm{C} 2$ 時間（×10,000 倍 $)$

写真-1 電子顕微鏡写真 (加熱前と $1,000^{\circ} \mathrm{C} 2$ 時間加熱後)

産のものであり，直径 $0.02 \sim 0.2 \mu \mathrm{m}$ ，長さ $1 \sim 20 \mu \mathrm{m}$ の中 空状繊維単位が集まり，蛇の肌のようでカール状の繊維

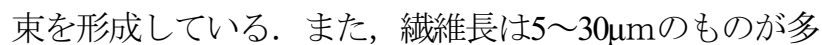
い. アモサイトは南アフリカ共和国Transvaal州産で直径 $0.1 \sim 0.2 \mu \mathrm{m}$, 繊維長は $1 \sim 10 \mu \mathrm{m}$ 程度のものが多い. クロ シドライトは南アフリカ共和国Cape州産で直径 $0.1 \sim 1 \mu \mathrm{m}$, 繊維長は2〜数 $10 \mu \mathrm{m}$ と幅広く分布している.

また，加熱溶融のために使用した薬液は，実際のアス
ベストの工事に用いられているカルシウム化合物系のも のであり，カルシウム化合物含有量がそれぞれ $35 \mathrm{w} \%$, 20w\%のものを用いた。薬液の概要を表-2に示す.

\section{(2) アスベストの加熱分解}

始めに，比較の資料とする目的でアスベストのみを加 熱した場合の変化について検討を行った。前述の3種の アスベスト標準試料を磁性るつぼの中に入れ，電気炉 


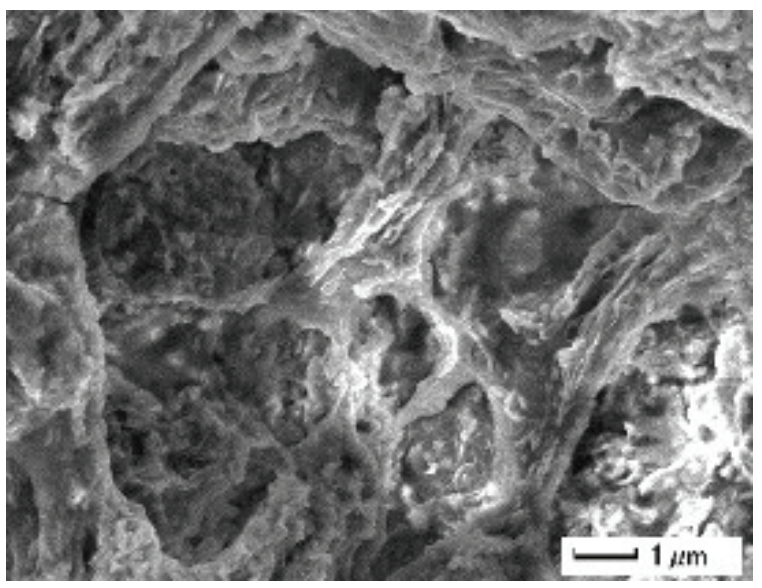

$\mathrm{R}$ 剂添加 $(\times 10,000$ 倍 $)$

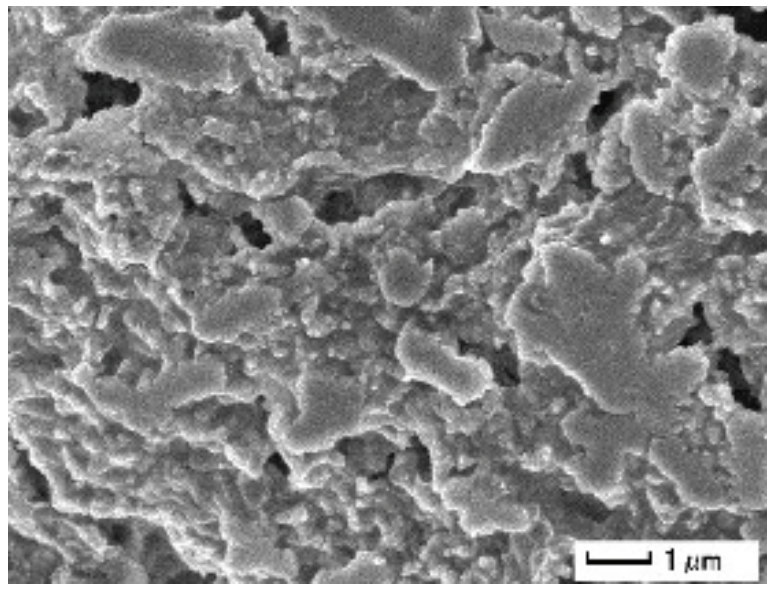

$\mathrm{P}$ 剂添加 $(\times 10,000$ 倍 $)$

写真-2 電子顕微鏡写真 (クリソタイル $700^{\circ} \mathrm{C} 1$ 時間加熱)

(マッフル炉) 内で，常温から90分間で所定の温度 $\left(1,000^{\circ} \mathrm{C}\right)$ まで上昇させた後，2時間保持し，その後， 炉内で自然冷却した。冷却後, 得られた焼成物について, 走査型電子顕微鏡（SEM：日本電子株式会社製，JSM6335F）で観察を行った. 観察結果を写真-1に示す. $\mathrm{SEM}$ 写真より， $1,000^{\circ} \mathrm{C} 2$ 時間加熱では，クリソタイルお よびアモサイトの䋊維形態は保持されており，クロシド ライトは繊維形態がかなり崩れ，溶融しているように見 受けられる.これはアスベストの融点が，クリソタイル $1,521^{\circ} \mathrm{C}$ ，アモサイト $1,399^{\circ} \mathrm{C}$, クロシドライト $1,193^{\circ} \mathrm{C}$ と 種類によって若干の違いがあり, クロシドライトについ ては, 固相線温度 (一部が溶け始める温度) が比較的低 かったため, $1,000^{\circ} \mathrm{C} 2$ 時間の加熱で一部溶けたものと推 測される.

\section{(3)薬液を用いたクリソタイルの加熱分解}

写真-1に示すように $1,000^{\circ} \mathrm{C} 2$ 時間の加熱では，アスベ ストの䋊維形態は崩れない，そこで，既往の小島らの実 験》17)を参考に，カルシウム化合物を主成分とする工事 用薬液を添加して，アスベストの低温加熱分解を試みた. 小島らの実験によるとフロン化合物あるいは，塩化物を 添加することにより, アスベストの分解温度を下げるこ とができる。

本研究では，実際のアスベスト工事で用いられている カルシウム化合物を主成分とする除去用剂（R剂）とこ れに接着剤を混ぜた封じ込め用剤（P剂）の2種類を用意 した.この薬液の概要を表-2に示す．2種類の薬液を用 いたのは，実際の工事では，除去時に薬液を噴霧・浸潤 したアスベスト廃葉物が発生すること, 封じ込め時には 薬液を噴霧・注入して固化させ，将来の解体除去時に廃 棄物が放出されることを考慮したためである.

実験パターンを表-3に示す．最初に，実験では磁性る つぼに入れたクリソタイル試料に薬液を添加し, 電気炉 (マッフル炉) 内で，常温から60分間で所定の温度
表-3 実験パターン

\begin{tabular}{|c|c|c|c|}
\hline 試料 & 添加剤 & 溶融温度 & 溶融時間 \\
\hline クリソタイル & R剂 (除去用鼡) & $700^{\circ} \mathrm{C}$ & 2時間 \\
\hline クリソタイル & 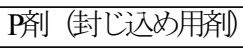 & $700^{\circ} \mathrm{C}$ & 2時間 \\
\hline クリソタイル & R剂 (除去用凨) & $700^{\circ} \mathrm{C}$ & 1時間 \\
\hline クリソタイル & P凬（封じ込め用凪） & $700^{\circ} \mathrm{C}$ & 1時間 \\
\hline
\end{tabular}

$\left(700^{\circ} \mathrm{C}\right)$ まで上昇させた後，2時間保持し，その後，炉 内で自然冷却した. この際, クリソタイル試料と薬液は 重量比1：1の割合で添加した．添加割合については，別 途行った実験から薬液が半分程度でも効果があることを 確認しているが，実際の工事では，1：1以上の割合で散 布するため，実際の工事にあわせて1：1とした。 また， クリソタイル試料と薬液は, 特に混ぜ合わせることは行 わず，実際の除去工事と同様に毛細管現象による浸透の みで行った.

加熱処理されたクリソタイル試料の組織の変化をSEM で観察を行ったが，結果はどちらのクリソタイル試料か らも針状組織は確認されず，クリソタイルの針状組織が 崩壊していることがわかった。

さらに $700^{\circ} \mathrm{C}$ での加熱時間を 1 時間に短縮して，同様の 実験を試みた。そのSEM観察の結果を写真-2に示す.

写真-2より，1時間の加熱でもクリソタイルの針状組 織は崩壊しており， $700^{\circ} \mathrm{C}$ 温度を維持すれば加熱時間 に関しては1時間でも十分であることがわかった。

\section{(4) 薬液によるクロシドライト, アモサイトの加熱分解}

前述のクリソタイルはアスベストの世界生産量の9割 以上を占めており，それゆえアスベストといえばクリソ タイルのことを指し，融点がアスベスト中では最も高い のでアスベスト廃棄物の低温無害化についてはクリソタ イルを中心に考えればよい. しかし，建材には角閃石系 のクロシドライトやアモサイトも使用されており，しか も中皮腫発症の関連性については, Pooleyの疫学的研究 で，角閃石系アスベストの方が密接な関係にあることが 


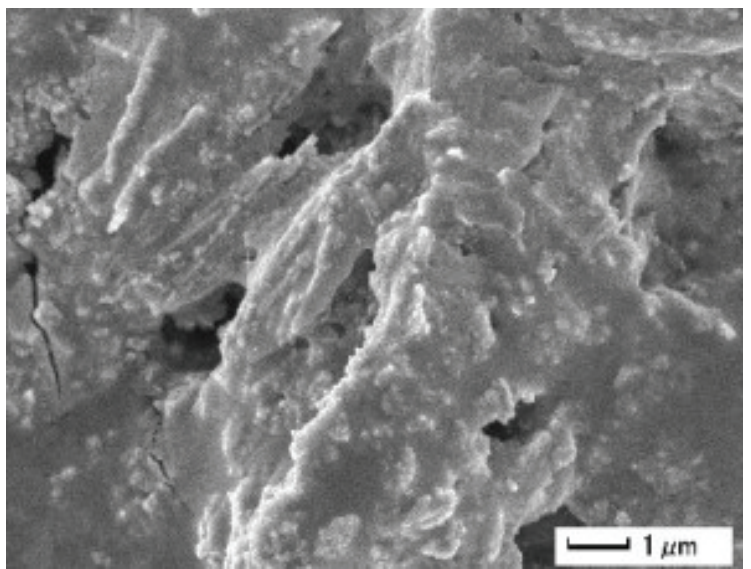

$\mathrm{R}$ 剂添加 $(\times 10,000$ 倍 $)$

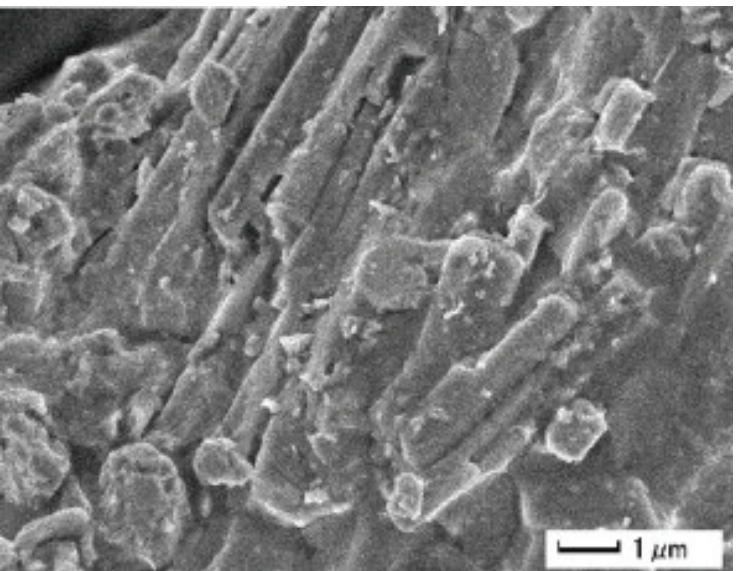

P剤添加 $(\times 10,000$ 倍 $)$

写真-3 電子顕微鏡写真（クロシドライト $700^{\circ} \mathrm{C} 1$ 時間加熱）

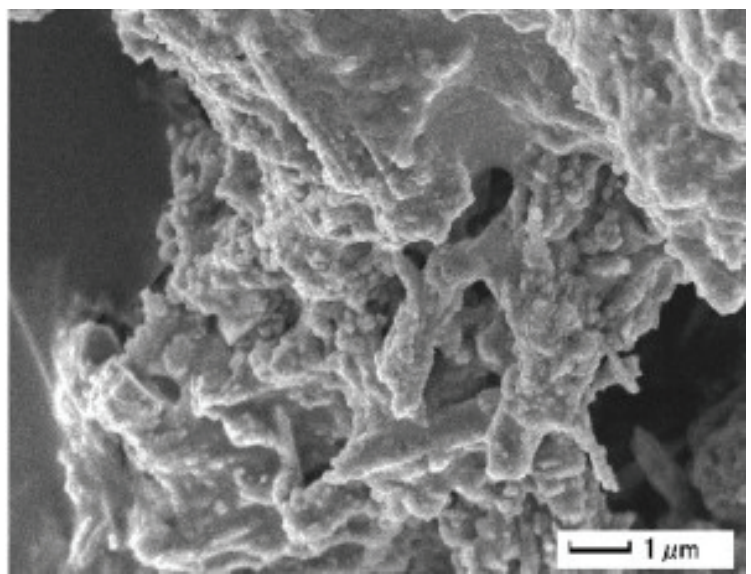

R 剂添加 $(\times 10,000$ 倍 $)$

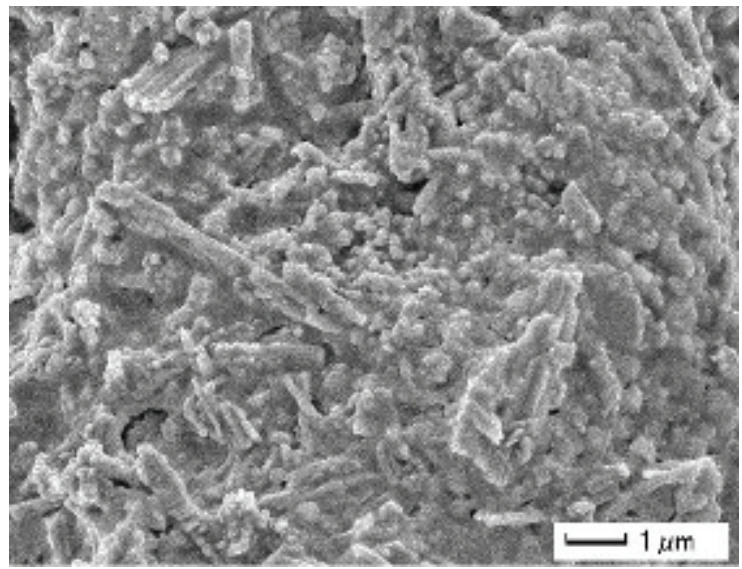

$\mathrm{P}$ 剂添加 $(\times 10,000$ 倍 $)$

写真-4 電子顕微鏡写真（アモサイト $700^{\circ} \mathrm{C} 1$ 時間加熱）

確認されており，その危険性はクリソタイルの100～500 倍という報告もある ${ }^{18)}$.

また，実際のアスベストの対策工事や廃棄物処理にお いては，これらの含有も有り得ることや，クロシドライ トやアモサイトに関しては，無害化研究の成果について の詳述もほとんどないため，今回クリソタイルと同様の 実験を行い，今後クリソタイルを代表として実験確認を 進めれば，アスベスト全体について包括できることの確 認を行った.

薬液は，前述のカルシウム化合物を主成分とする工事 用薬液 $\mathrm{R}$ 剂と $\mathrm{P}$ 㓮を用意し，クロシドライト試料と薬液 は特に混ぜ合わせず，重量比1：1の割合で添加した。ま た，アモサイト試料についても同様に薬液を添加した.

そして，磁性るつぼに入れたそれぞれの試料を電気炉内

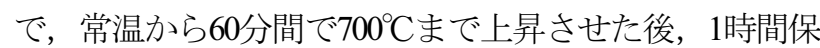
持し, その後，炉内で自然冷却した。加熱後のそれらの SEM観察結果を写真-3および写真-4に示す.

両者とも完全に針状組織は消失しており，クロシドラ イトおよびアモサイトについてもクリソタイルと同様に, 薬液添加による低温加熱で無害化が可能であることがわ かった。

\section{(5) セメントで固化されたアスベストの加熱分解}

前述の一連の実験はアスベストの標準試料を用いたも のであるが，実際にはアスベスト単体の廃棄物はまれで あり，多くは吹付けアスベストのようにアスベストをセ メントなど他成分で被覆した状態で排出されることが多 い. アスベストの使用形態として，紡織品としてアスベ ストが単独で使用される量はわずかで，セメントとアス ベストの複合材料として使用される場合がほとんどであ る.

吹付けアスベストのセメント成分がアスベスト表面へ の薬液の浸透を阻害する可能性があるため, 実験用の吹 付けアスベストは，アスベスト／セメントの重量比が異 なる 2 種類の試料を用意した. クリソタイルと普通ポル トランドセメントの重量比を，9:1（試料a）と，1:9 （試料b）とした。これは，吸音材などのアスベスト成 分の多い材料と通常使用されている程度の材料を想定し たためである。また，水を全重量と同程度加えて，材料 が均一となるまで練り混ぜた。 その後, 混合物を静置さ せ，常温で固化させた。 


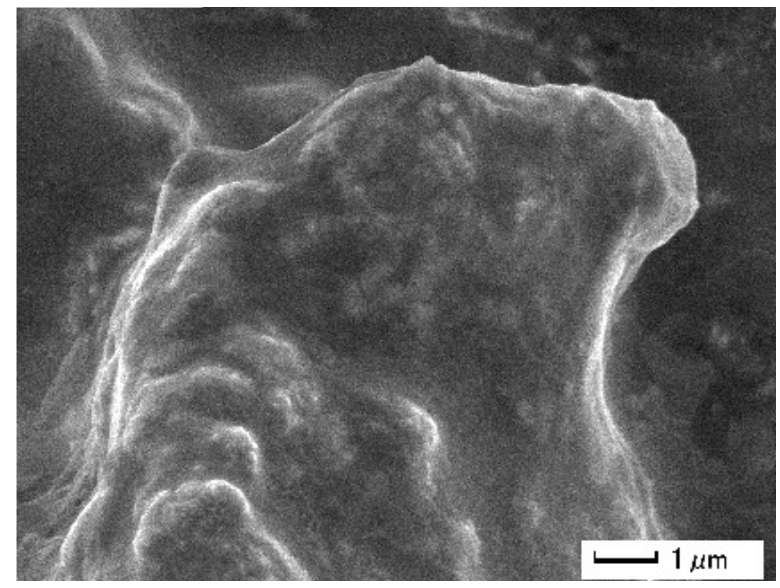

試料 a（×10,000 倍）

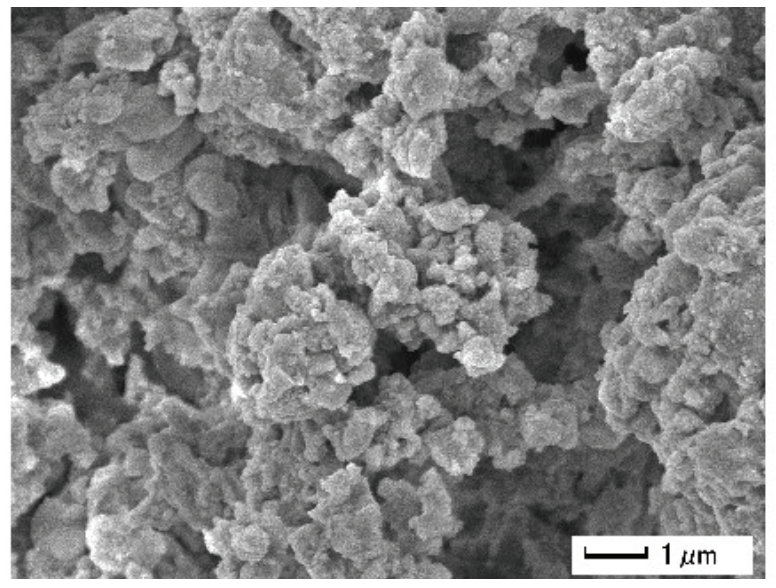

試料 b（×10,000 倍）

写真 -5 電子顕微鏡写真 (クリソタイル十セメント $700^{\circ} \mathrm{C} 1$ 時間加熱)

表-4 X線回折分析の測定条件

\begin{tabular}{|l|l|}
\hline \multicolumn{1}{|c|}{ 項目 } & \multicolumn{1}{c|}{ 条件 } \\
\hline X線対陰極 & 銅 $(\mathrm{Cu})$ \\
\hline コニニオメー & RINT2000広角ゴニオメータ \\
\hline 管電圧 $/$ 管電流 & $40 \mathrm{kV} / 200 \mathrm{~mA}$ \\
\hline & 発散スリット $: 1 / 2^{\circ}$ \\
スリット条件 & 散乱スリット: $12^{\circ}$ \\
& 受光スリット $: 0.15 \mathrm{~mm}$ \\
\hline 走査速度 & $2.4^{\circ} /$ 分 \\
\hline 走査範讲 & $0.02^{\circ}$ ステップ \\
\hline 走査軸 & $5.0^{\circ} \sim 80.0^{\circ}$ \\
\hline
\end{tabular}

表-5 X線回折分析に用いた試料

\begin{tabular}{|c|c|}
\hline 試料No. & 試料 \\
\hline 試料1 & でんぷん \\
\hline 試料2 & クリソタイル \\
\hline 試料3 & クリソタイル+でんぷん \\
\hline 試料4 & クリソタイル+R剤，1時間加熱，でんぷん添加 \\
\hline 試料5 & クリソタイル $+\mathrm{P}$ 戍，1時間加熱, でんぷん添加 \\
\hline
\end{tabular}

標淮試料と薬液を用いたこれまでの試験と同様に，磁 性るつぼに試料を入れ, 薬液R剤を重量比 1 : 1で添加し た. 電気炉内で常温から60分で $700^{\circ} \mathrm{C}$ まで上昇させた後, 1時間加熱保持し，その後，炬内で自然冷却した。 その SEMによる観察結果を写真-5に示す.

試料a はクリソタイルの含有量が多いため, 標準試料 と薬液のみで行った加熱試験とほぼ同等の溶融状態を呈 し，アスベストを示寸針状繊維形態の物質は全く確認さ れなかった. また，試料b はセメント成分が多いため, 全体として塊状であり, 塊の内部に䋊維が残っているこ とも考えられる. そこで，この試料を乳鉢で粉砕し，再 度SEM観察を行ったが，アスベスト特有の針状䋊維形態 は発見されなかった。

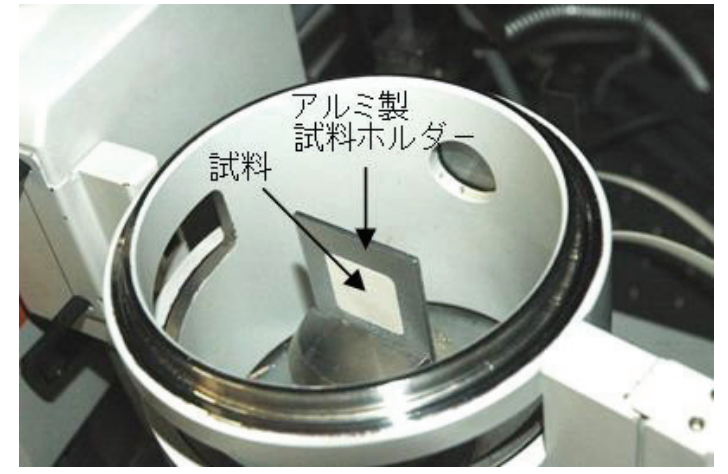

写真-6 X 線回折装置の試料ホルダー

\section{(6) X線回折による定性分析}

それぞれの試験において，SEM観察によって形状的な 様子を確認してきたが，各段階においてどのように成分 が変化しているのかを粉末X線回折分析装置（リガク 2500HF）を用いて確認を行った.

X線回折法は，結晶にX線を照射することにより生じ た結晶からのX線反射を測定し，その試料に含まれてい る結晶構造を調べる方法である.アスベストは天然鉱物 であり，その種類ごとに固有な結晶構造を有している. したがって，この手法による分析でアスベストの種類を 特定することが可能である ${ }^{19121) . ~}$ 表-4にX線回折分析の 測定条件を示寸．また，表-5にX線回折分析に用いた試 料を示す.X線回折分析では, 写真-6に示すような試料 ホルダーに試料をセットし分析を行うが，クリソタイル の標準試料に薬液を添加して $700^{\circ} \mathrm{C}$ で加熱した焼成物は, 結晶水を含む鉱物もあり，時間の経過にともない，空気 中の水分を吸収して水溶液になろうとする，いわゆる潮 解性を有するため, そのままでは, 試料ホルダーから脱 落してしまう。そこで，焼成物に「でんぷん」を添加し て，X線回折装置に装着した，そのため，でんぷんの波 形を取り除く目的で，でんぷんのみの回折分析も行った. なお，添加割合は，重量比で焼成物1に対して，でんぷ ん3で行った. 図-1に試料 1 , 試料 2 , 試料 $3 の X$ 線回折に 


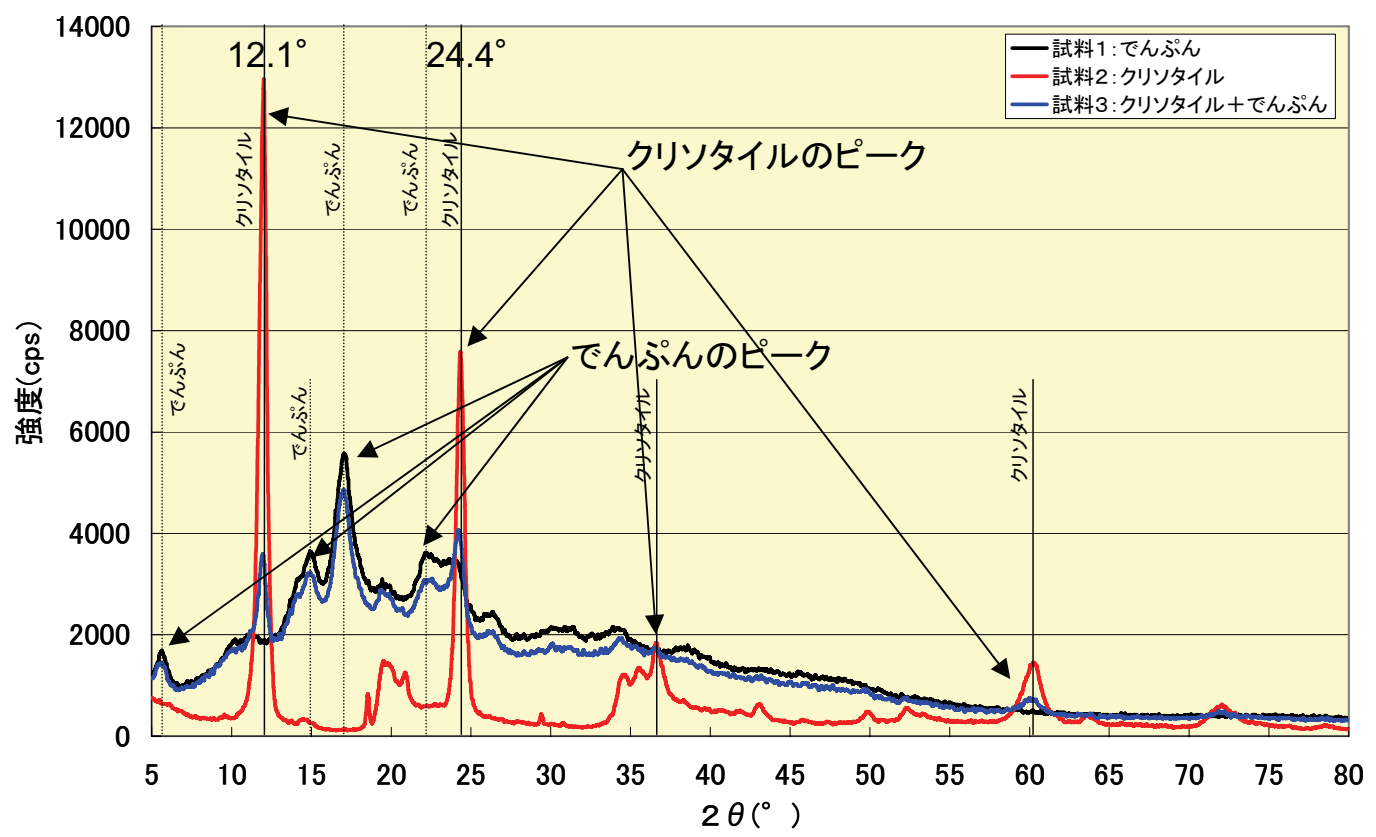

図-1 X 線回折結果 (試料 $1,2,3$ )

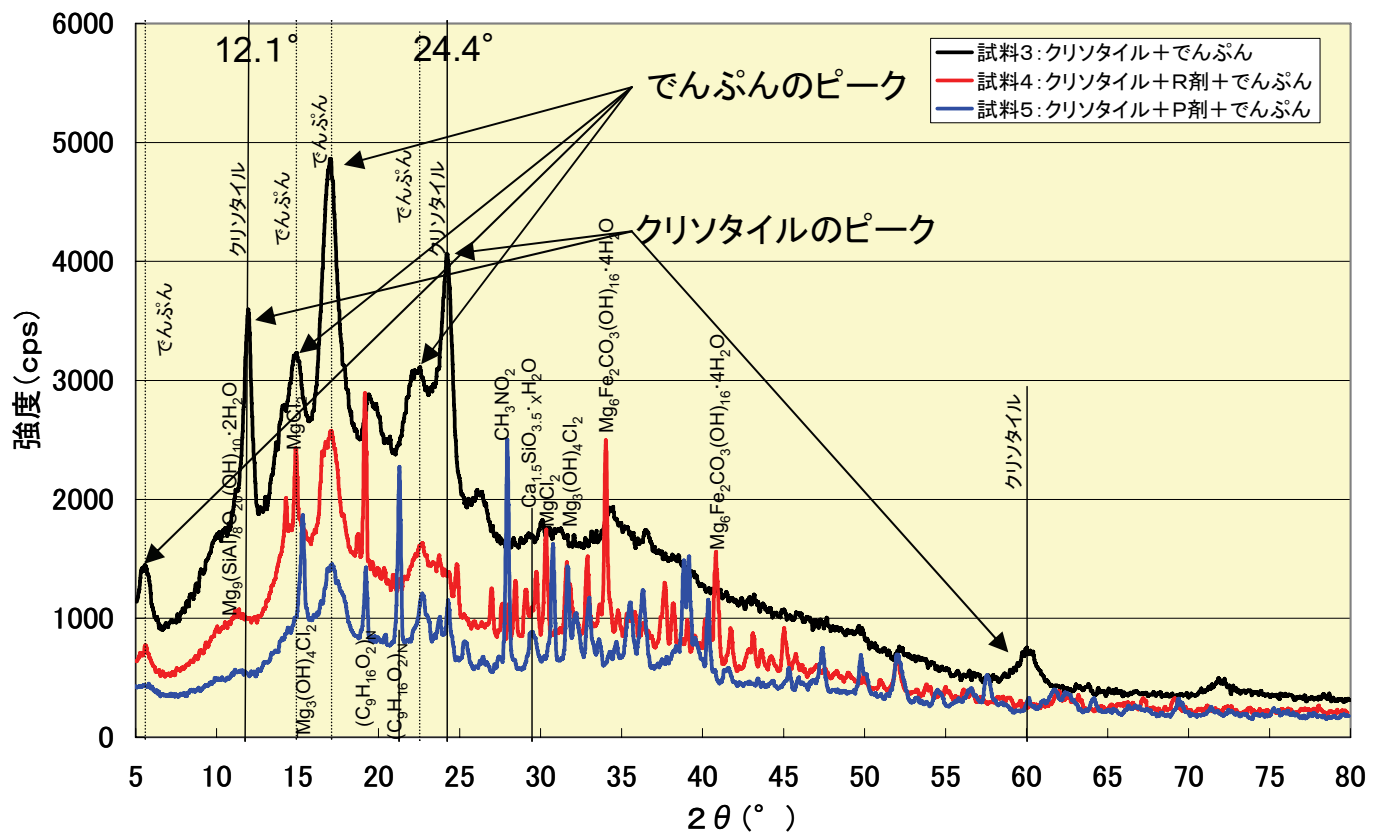

図-2 X 線回折結果 (試料 $3,4,5)$

よる分析結果を示す．青線の試料3は，クリソタイルと でんぷんが混ざったものであるが，クリソタイルのピー クとでんぷんのピークの両方が現れており，ピークの強 度は小さくなるものの, クリソタイルのピークが隠れて しまうようなことはない.

図-2に試料3，試料4，試料5のX線回折による分析結 果を示す. 試料4（クリソタイル $+\mathrm{R}$ 剂 +1 時間加熱，で んぷん添加）および試料5（クリソタイル $+\mathrm{P}$ 剂 +1 時間 加熱，でんぷん添加）では，クリソタイルの特性を示す ピーク（2 $\theta$ で $12.1^{\circ}$ と $24.4^{\circ} ）$ が見られないため，所定 の加熱によりクリソタイルの成分は消失したことが確認
された。

試料4の焼成物のX線回折パターンからは, $\mathrm{MgCl}_{2}$, $\mathrm{Mg}_{6} \mathrm{Fe}_{2} \mathrm{CO}_{3}(\mathrm{OH})_{16} \cdot 4 \mathrm{H}_{2} \mathrm{O}, \mathrm{Mg}_{9}\left(\mathrm{SiAl}_{8} \mathrm{O}_{20}(\mathrm{OH})_{10} \cdot 2 \mathrm{H}_{2} \mathrm{O}\right.$ の回折 強度が大きく検出され, 試料 5 の結果からは, $\mathrm{Mg}_{3}(\mathrm{OH})_{4} \mathrm{Cl}_{2}, \quad \mathrm{Ca}_{15} \mathrm{SiO}_{3.5} \cdot \mathrm{xH}_{2} \mathrm{O}$ のピークが顕著に表れてお り，マグネシウム $(\mathrm{Mg})$ とケイ素 $(\mathrm{Si})$ の結合が切り離され ていることが分かる，そして，両方の焼成物からともク リソタイルの存在を示す特有のピークは確認されなかっ た.つまり，クリソタイルはカルシウム化合物との混合 と加熱によって結晶構造が変化し， $700^{\circ} \mathrm{C}$ とう比較的 低温での無害化が可能と言える. 


\section{4. 吹付けアスベストの加熱溶融実験}

平成18年9月に仙台市内の某駐車場において，P剤を用 いた封じ込め工事を実施し，その場で採取した吹付けア スベストの試料を使用して，アスベスト以外の成分が混 入している状態でも，これまでの実験の成果が適応でき るかを検討した．写真-7に工事を行った現場の状況を 示す. 工事に際し，吹付けアスベストの含有構成を試験 機関にて確認したところ，アスベスト成分としては表-6 に示すようにクロシドライト $24 \%$ ，クリソタイル $3 \%$ ガ 含まれていた，その他にセメントや砂などが混合されて Wた.

\section{（1）薬液を含有をした吹付けアスベストの溶融}

表-7に吹付け材試料の概要を示寸. 試料6は吹付けア スベストそのもののであり，そのSEMによる観察結果を 写真-8に，またX線回折結果を図-3に示寸，写真からは アスベストの針状組織が観察でき，X線回折図からは $12.1^{\circ}$ と $24.4^{\circ}$ 付近にクリソタイルの小さなピークが現 れ，また， $10.3^{\circ}$ と $29^{\circ}$ 付近にクロシドライトあるいは アモサイトの大きなピークが現れている. クロシドライ トとアモサイトは, $10.3^{\circ}$ と $29^{\circ}$ 付近にピークが現れる が，この両者の識別は難しく $10.3^{\circ}$ のピークでは識別不 能である.これらの識別には，29 $9^{\circ}$ 付近のピークを正確

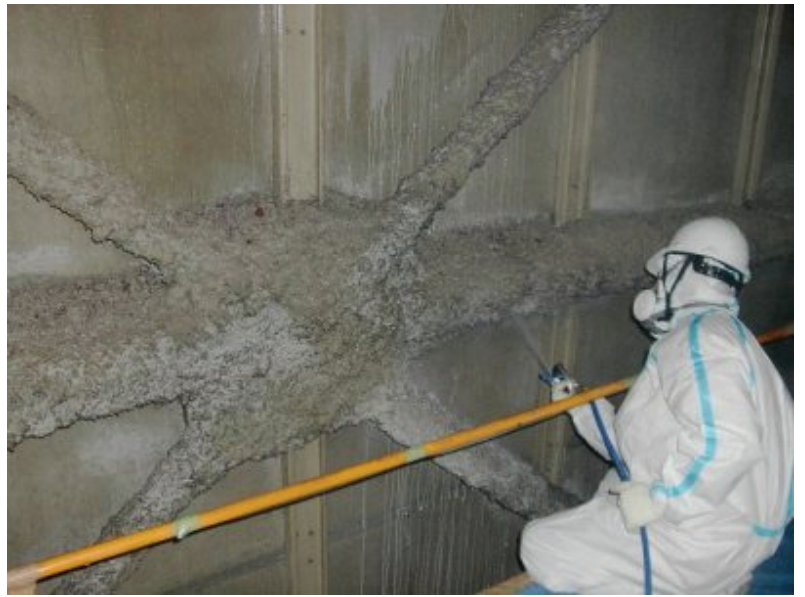

写真-7＼cjkstart吹付けアスベストの封じ込め作業

表-6 吹付け材の成分

\begin{tabular}{|c|c|}
\hline 種類 & 含有量 \\
\hline クリソタイル & $3 \%$ \\
\hline クロシドライト & $24 \%$ \\
\hline セメント, 砂等 & $73 \%$ \\
\hline
\end{tabular}

表-7 吹付け材試料

\begin{tabular}{|c|c|}
\hline 試料 & 試料の詳細 \\
\hline 試料 6 & 吹付け材（アスベスト）そのもの \\
\hline 試料 7 & 吹付け材 $+\mathrm{P}$ 斉噴霧・注入 $+700^{\circ} \mathrm{C} 1$ 時間加熱 \\
\hline 試料 8 & $\begin{array}{l}\text { 吹付け材+P凧膹霧・注入+R 剤添加 } \\
+700^{\circ} \mathrm{C} 1 \text { 時間加熱 }\end{array}$ \\
\hline
\end{tabular}

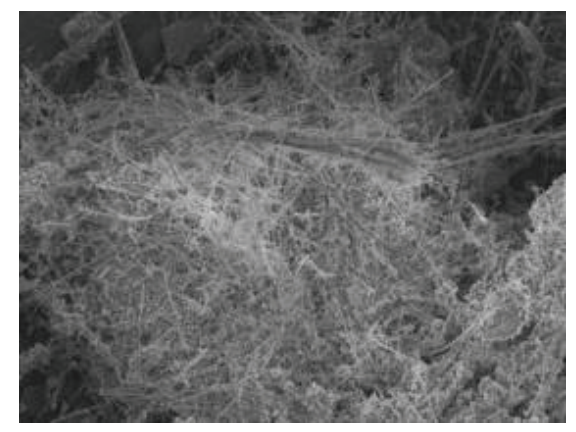

$\times 1,000$ 倍

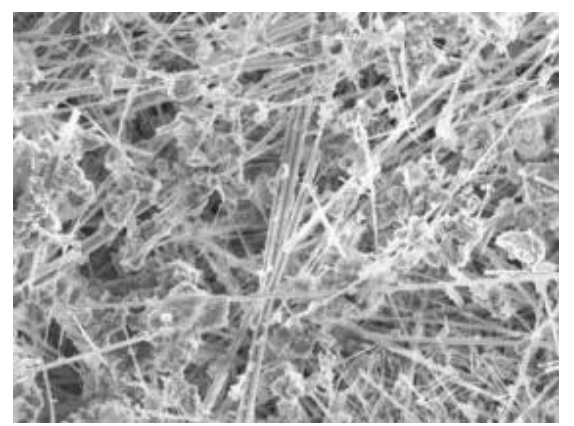

$\times 5,000$ 倍

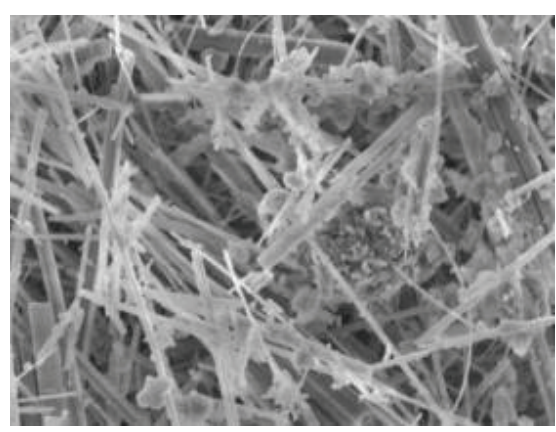

$\times 10,000$ 倍

写真-8 吹付けアスベスト電子顕微鏡写真 (試料 6 : 処理前)

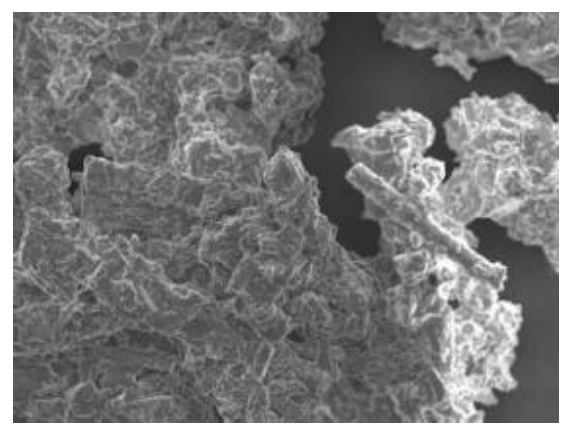

$\times 1,000$ 倍

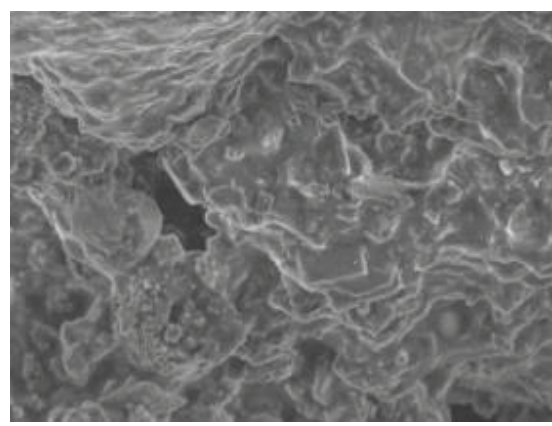

$\times 5,000$ 倍

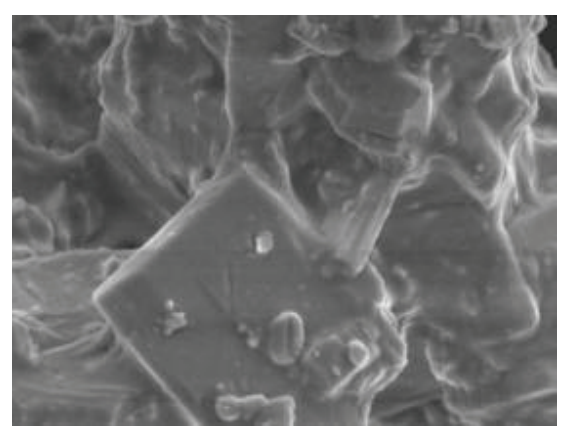

$\times 10,000$ 倍

写真-9 吹付けアスベスト電子顕微鏡写真（試料 $7:$ P 剂含浸十加熱処理後） 


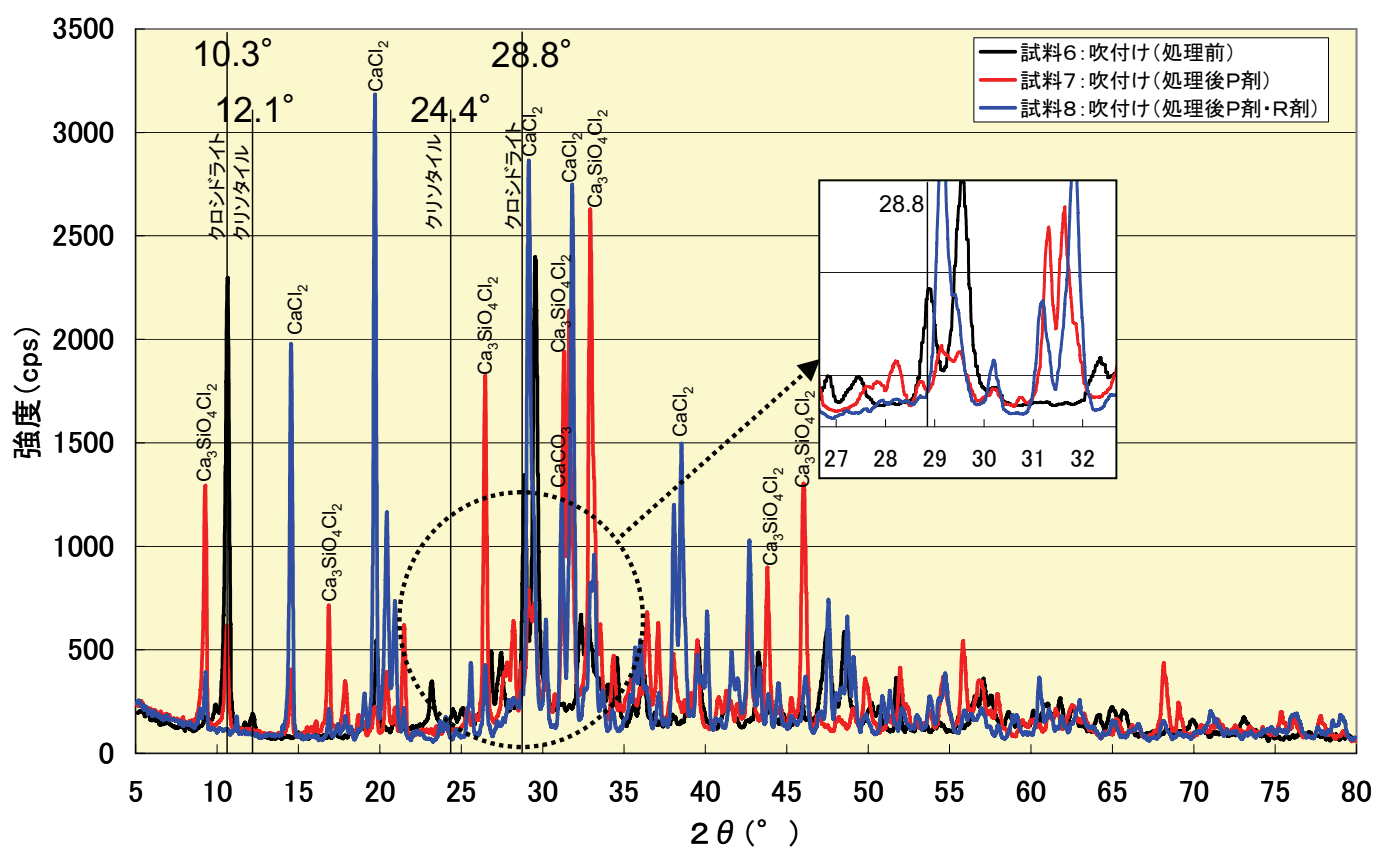

図-3 X線回折結果（試料 6,7,8)

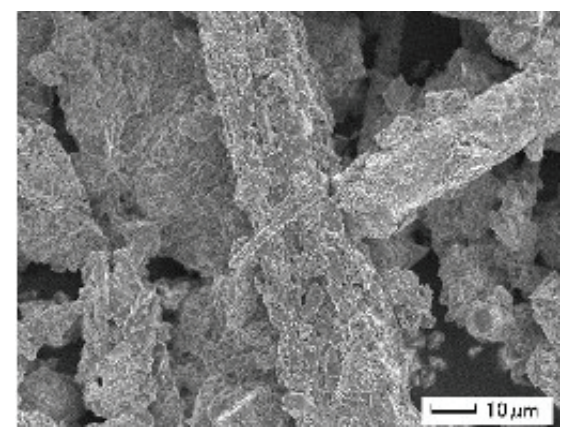

$\times 1,000$ 倍

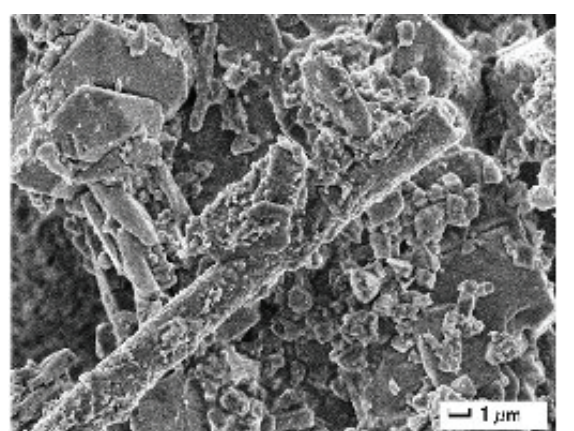

$\times 5,000$ 倍

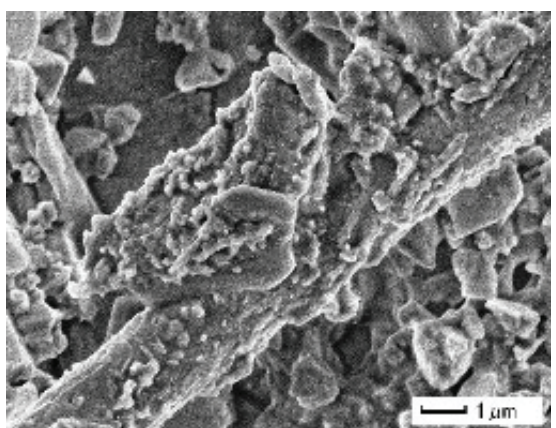

$\times 10,000$ 倍

写真-10 吹付けアスベスト電子顕微鏡写真（試料 $8: \mathrm{P}$ 剂含浸 $+\mathrm{R}$ 剂添加十加熱処理後）

に測定する必要があり，ピーク位置が $28.8^{\circ}$ ならクロシ ドライト，29.1 であればアモサイトとなる．図-3中に $30^{\circ}$ 付近に拡大図を示すが，試料6（黒色）は，28.8 付 近にピーク位置があることから本分析においてもクロシ ドライトと判断される. 次に, 試料7は, 薬液含浸した 加熱処理後の試料である. 封じ込め工事でP阂の噴霧・ 注入を完了した吹付けアスベストを一部採取し，それを 磁性るつぼに入れ，電気炉内で常温から60分で所定の温 度 $\left(700^{\circ} \mathrm{C}\right)$ まで上昇させた. 1時間の加熱保持後, 電気 炉の電源を切り，るつぼの試料は自然冷却させた。加熱 処理された試料7の組織変化についてSEM観察を行った. その結果を写真-9に示す.この写真からは, アスベスト の特徵である針状組織は確認できなかった。

次に，X線回折による分析結果を図-3に赤線で示す. $\mathrm{Ca}_{3} \mathrm{SiO}_{4} \mathrm{Cl}_{2}, \mathrm{CaCl}_{2}$ などの生成物の他にクリソタイル, ク ロシドライトも検出されている. それぞれピークは小さ いものの, クリソタイル（特有ピークは $2 \theta$ で $12.1^{\circ}$ と $\left.24.4^{\circ}\right)$ ，クロシドライト（特有ピークは $2 \theta$ で $10.3^{\circ}$ と 28.8 ） はいくらか残存していることが分かる.つまり， X線回折の結果からは，アスベストを完全には消失する ことができなかったと言える.このような結果が生じた 原因として，以下のことが考えられる．1) セメントなど の混練物がアスベストと薬液の接触を阻害し，アスベス トの分解反応の進行が妨げられた．2)封じ込め工事にお ける薬液の所定注入量だけでは, 低温加熱でアスベスト を完全に消失させるには量的に足りないか，噴霧にさら があった．3)融点が高い方のクリソタイルの残存が顕著 でないのは，クリソタイルの含有量が少ないためである.

\section{(2) 薬液を追加添加した吹付けアスベストの溶融}

封じ込め工事後数年経過した状態の吹付けアスベスト を除去する場合には，除去用薬液R剂を噴霧・注入し湿 潤化して工事を行う。このようなことから，上記1), 2)を 解決するために，標準試料を用いた実験と同様に，試料 
8として，吹付けアスベスト試料（封じ込め工事後に採 取）とR剂の重量比を $1: 1 て ゙$ 混合して $700^{\circ} \mathrm{C}$ の温度で加熱 した．試料を磁性るつぼに入れ，電気炉内で常温から60 分間で $700^{\circ} \mathrm{C}$ まで上昇させ， 1 時間加熱保持して，その後, 炉内で自然冷却させた．得られた焼成物について，再度 SEMによる観察とX線回折分析を行った。その結果を写 真-10および図-3（青線）に示す，写真では針状組織は 確認できなかった。 そして今回のX線回折の結果からは, $\mathrm{CaCl}_{2}, \mathrm{CaCO}_{3}, \mathrm{SiO}_{2}$ などの成分を示寸回折強度が現れて おり，クリソタイルやクロシドライトの特徴のあるピー クは見られず，アスベストが消失したものと判断された。

\section{5. アスベスト成形板の薬液による加熱分解}

アスベスト成形板の低温溶融処理については，橋本ら が粉砕技術を併用することにより無害化の研究22), 23)を行 っているが，アスベスト成形板の適正処理を目指した研 究開発の実績は非常に少ない，筆者らは，吹付けアスベ ストと同様にアスベスト成形板についても，今回用いた 薬液を含浸させて低温加熱溶融に効果が期待できるか検 証を行った．非飛散性のアスベスト含有セメント板に関 しては，セメントで固化されており安全であるという理 由で，ほとんど一般廃棄物と同じ扱いになっている。こ
の先約10年後くらいには，高度経済成長期に建設された 建物や施設などの解体やリニューアルによって，セメン 卜板など数千万トン国内にあるアスベスト含有建築材の 廃棄量がピークを迎えると言われている，セメントの風 化や破砕によるアスベストの露出や飛散などの安全性の 問題が指摘され，アスベスト含有建築材の安全な処理技 術を確立することが求められている.

実験に使用したアスベスト成形板は，1962年に築造さ れた民間工場の外壁に使用されている波形スレート板の 一部である (写真-11参照)。築40年以上も経過してお

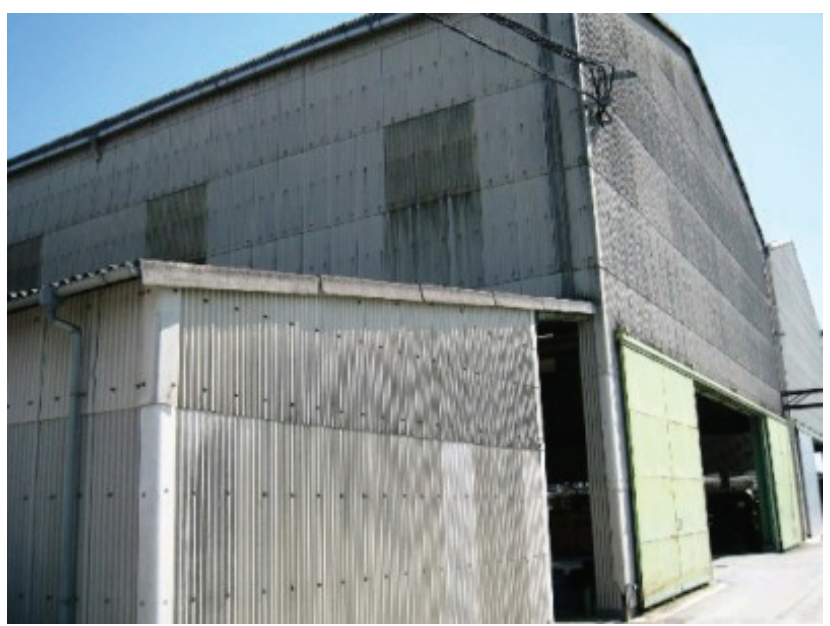

写真-11 工場の外壁に使用されている波形スレート板

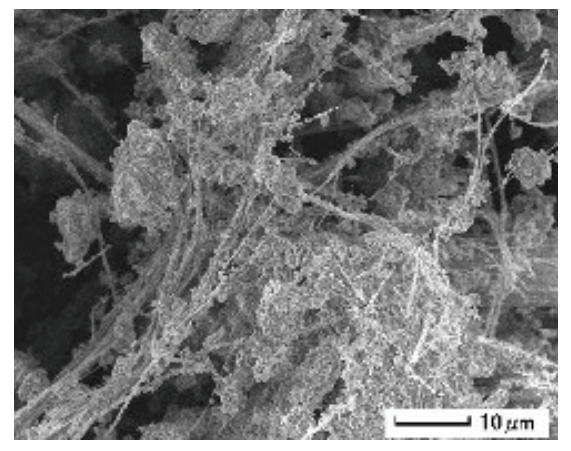

$\times 1,000$ 倍

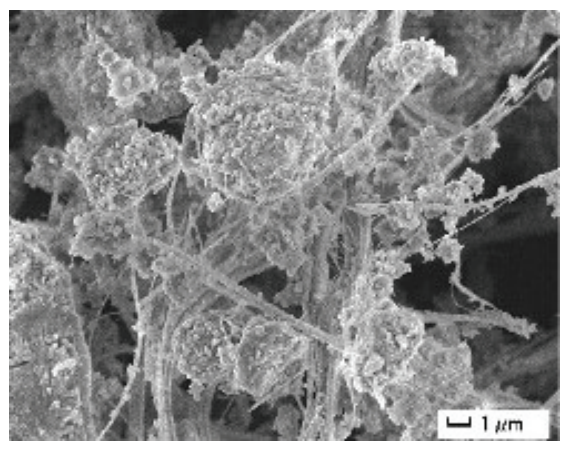

$\times 5,000$ 倍

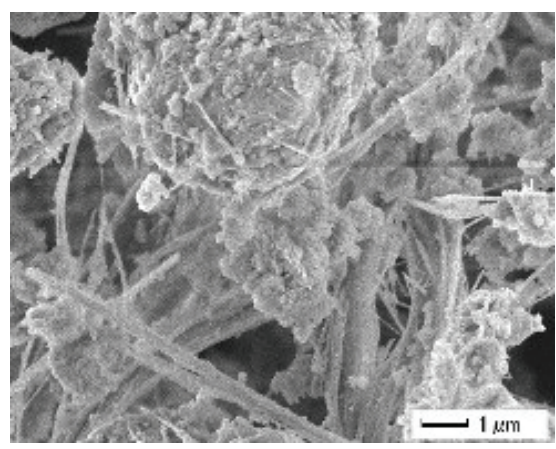

$\times 10,000$ 倍

写真-12 粉砕したスレート板の電子顕微鏡写真

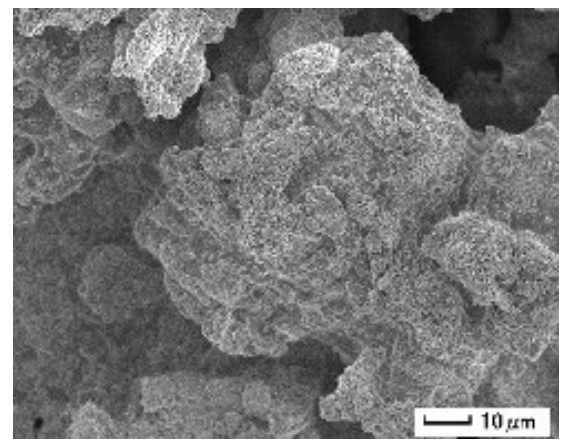

$\times 1,000$ 倍

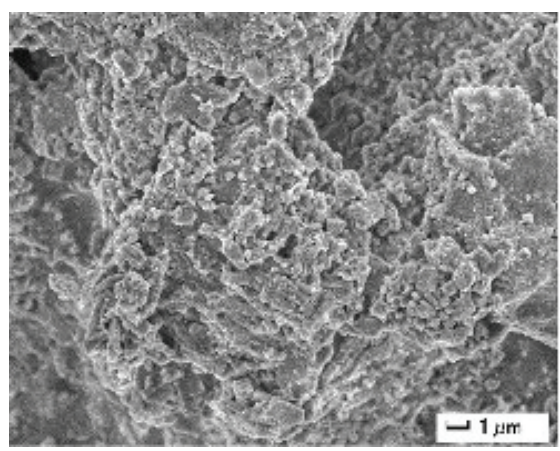

$\times 5,000$ 倍

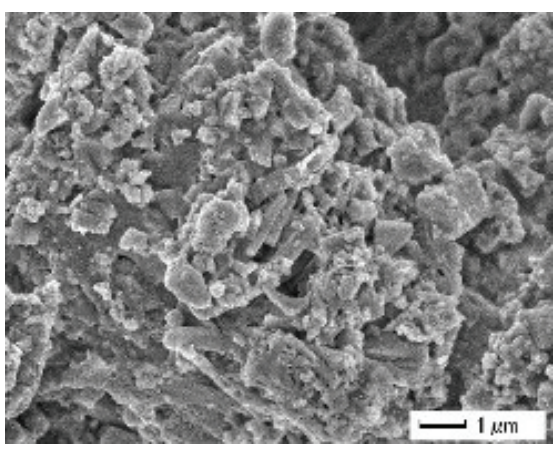

$\times 10,000$ 倍

写真-13 薬液十加熱処理後の電子顕微鏡写真 


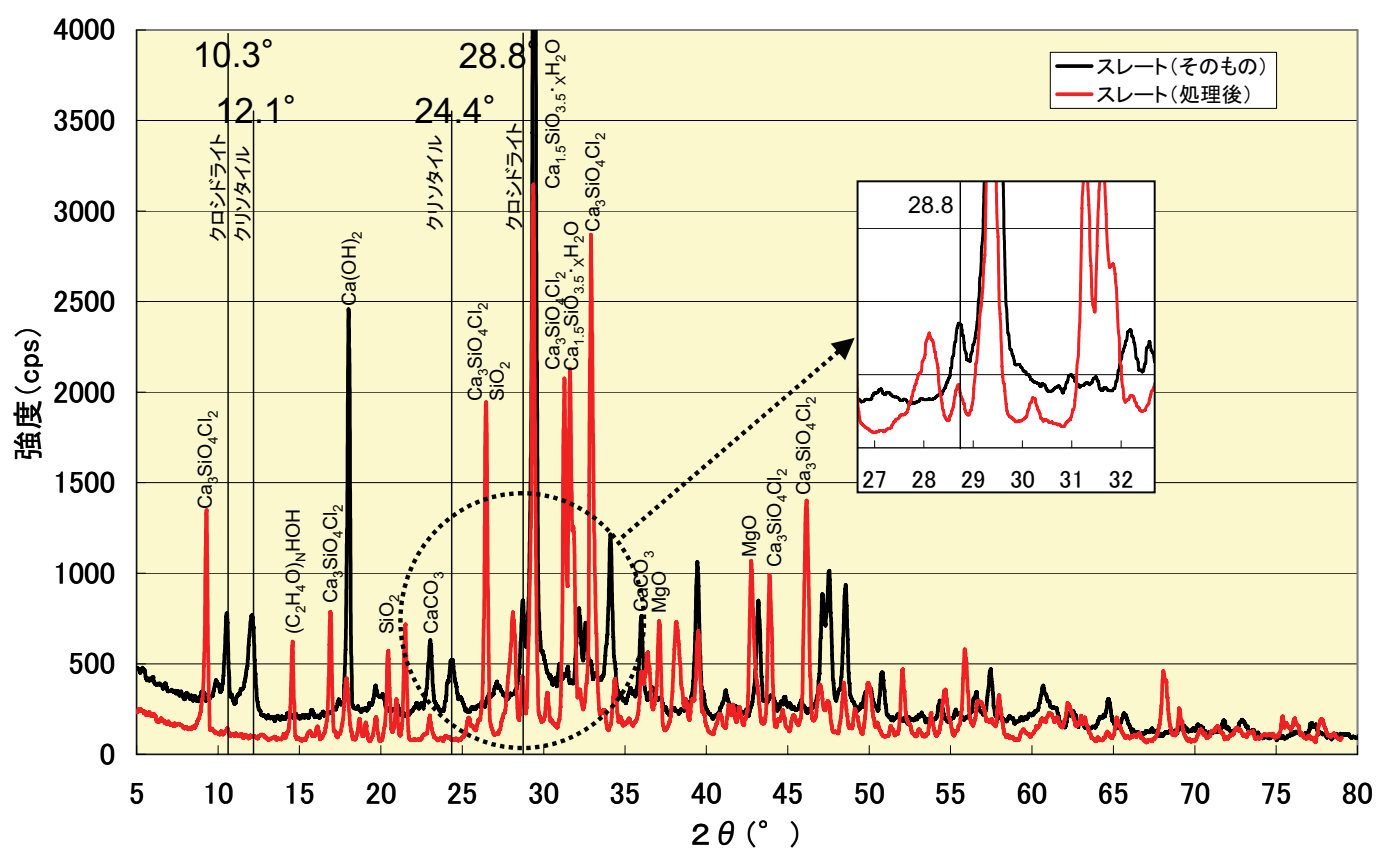

図-4 X線回折結果（スレート板）

り，製品表示やアスベスト製品であることを示す「a」

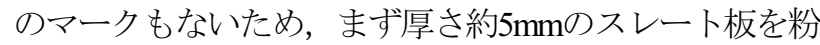
砕して，SEM観察およびX線回折分析によりアスベスト 含有の有無をチェックした，スレート板は約 $10 \mathrm{~mm} \times$ $10 \mathrm{~mm}$ の大ささに切り出し, 乳鉢に入れて粉砕した. 軽 く数秒吒いて粗砕し, 乳棒を使って人手により磨り潰し た. その粉砕された微細組織のSEM観察結果を写真-12 およびX線回折結果を図-4に示寸.

この写真のようにスレート板には，アスベストの針状 組織が多く観察された。スレート板がアスベストにより 繊維強化されている様子が伺えるとともに，破断すれば 簡単にアスベストが露出してしまうことを示している. またX線回折の結果からは, クリソタイルおよびクロシ ドライト（特有ピークが $2 \theta$ で $10.3^{\circ}$ および $28.8^{\circ}$ ）の含 有を示寸ピークが確認できた。 さらに，セメント成分の 含有を表す $\mathrm{CaCO}_{3} や \mathrm{Ca}(\mathrm{OH})_{2}$ などが検出された。この粉砕 したスレート板と薬液R剤を重量比1：1で混合して，常 温から 60 分間で $700^{\circ} \mathrm{C}$ の温度まで加熱し，その後1時間加 熱保持した. 加熱保持後, 電気炉の電源を切り, 磁性る つぼの中の試料は自然冷却させた。 その後のSEM観察の 結果を写真-13に，X線回折による分析結果を図-4に示 す.SEM観察写真からは針状組織は認められず，またX 線回折結果からは, $\mathrm{Ca}_{3} \mathrm{SiO}_{4} \mathrm{Cl}_{2}, \mathrm{MgO}, \mathrm{SiO}_{2}, \mathrm{Ca}_{1.5} \mathrm{SiO}_{35}$ • $\mathrm{xH}_{2} \mathrm{O}$ の回折強度が大きくなっていることが分かるが, クリソタイルおよびクロシドライトを表す特有のピーク は一切認められない. したがって，アスベストとしての 成分は消失したと判断される。この薬液が吹付けアスベ ストと同様に，スレート板の低温加熱溶融にも有効であ ることがわかった。

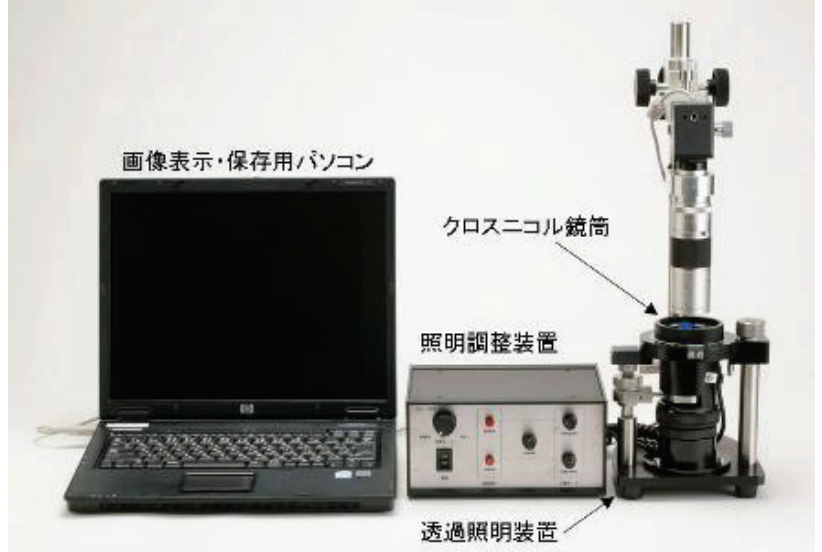

写真-14 アスベスト偏光判定装置

\section{6. 偏光判定法によるアスベスト成分の検出}

アスベスト成分の検出確認のためのSEMによる観察や X線回折分析は，検查機械の機能上，その操作や実験方 法についての実績や熟練が必要である. しかし，今後ア スベスト含有物の溶融や融解などの処理を行っていくた めには，実務上もつと簡易な方法にて日常の作業の中で もアスベストの存在の有無を確認できる方法が求められ る. そこで，JIS A 1481に記載されている偏光判定法に 基づいた検証が可能なポータブルタイプの装置（市販 品）を使って，上記結果との相関性を確認する，その偏 光判定装置を写真-14に示寸.

アスベストは鉱物繊維であり，アスペクト比3～10以 上の極めて細長い形状を呈するとともに，繊維束として も光学的異方性を示寸.このためクロスニコル装置で観 


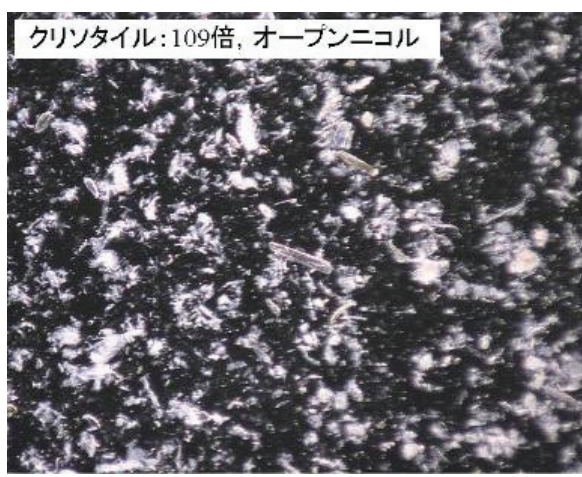

落射照明十透過照明（オープンニコル）

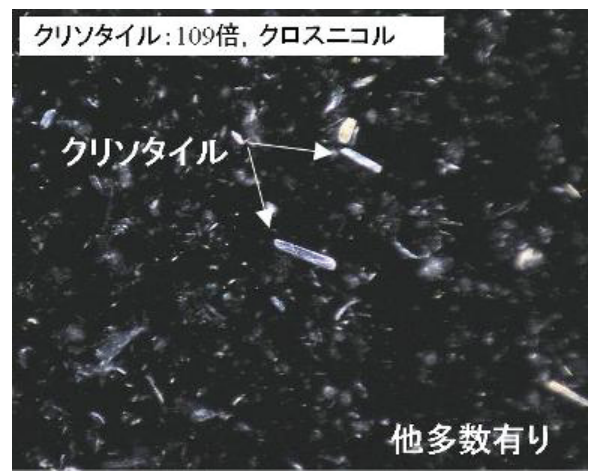

透過照明(クロスニコル)

(a) クリソタイル

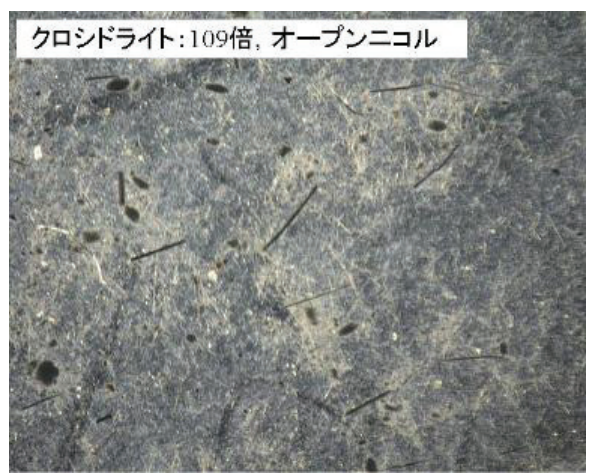

落射照明十透過照明（オープンニコル）

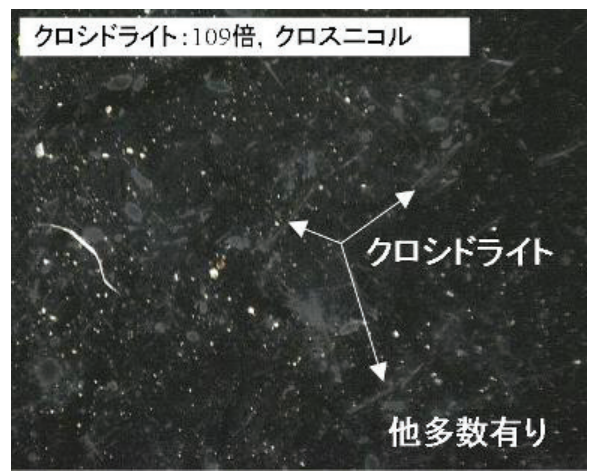

透過照明 (クロスニコル)

(b) クロシドライト

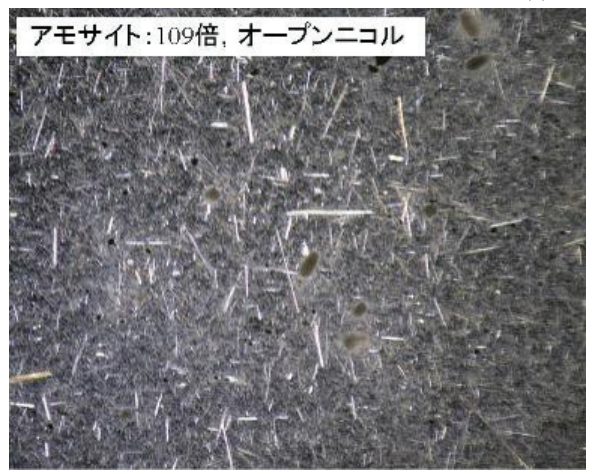

落射照明十透過照明（オープンニコル）

(c) アモサイ

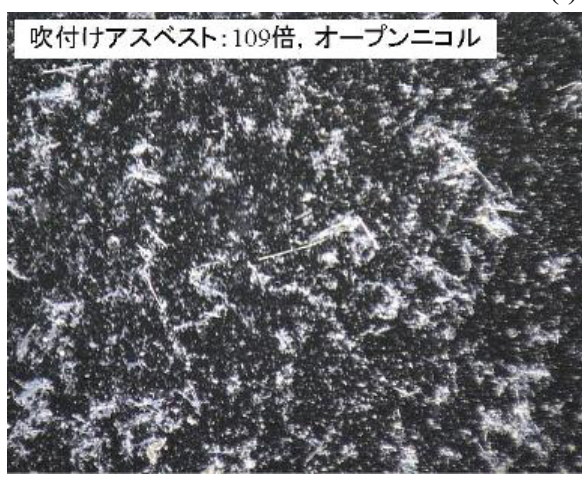

落射照明十透過照明（オープンニコル）

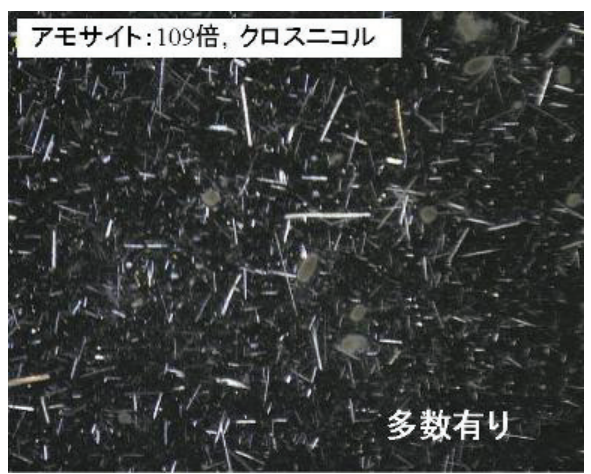

透過照明 (クロスニコル)

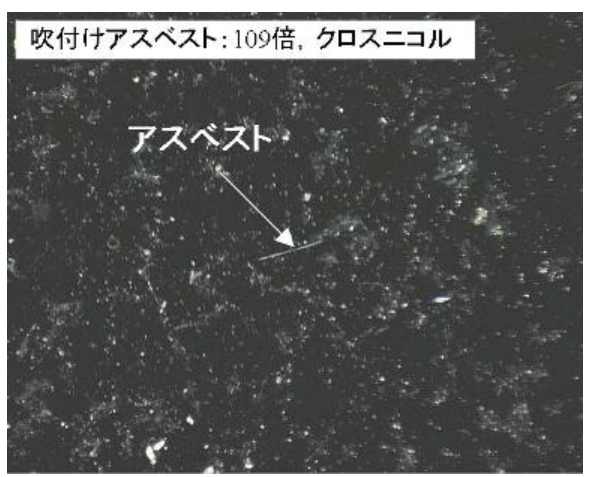

透過照明(クロスニコル)

(d) 仙台某駐車場吹付けアスベスト

写真-15 偏光判定法によるアスベストの検出

察すると，暗視野内で輝く繊維状物体として観察できる.

一方グラスウールやロックウールなどは形状が似てい
るが，クロスニコル下では常に消光して観察されるので, アスベストは光学性によって明確に識別できる.このよ 


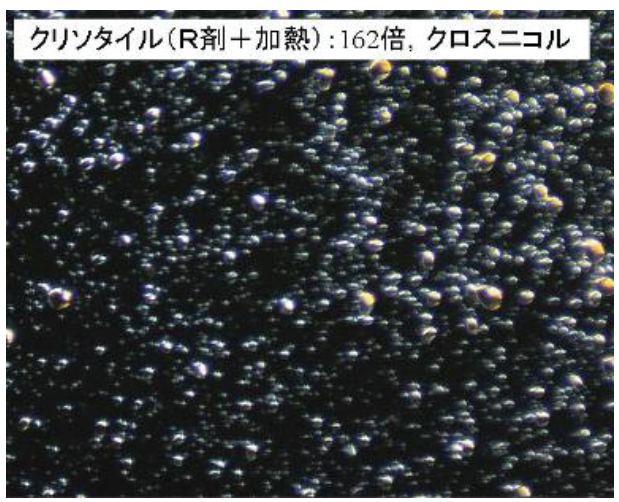

透過照明(クロスニコル) : R 剂十加熱

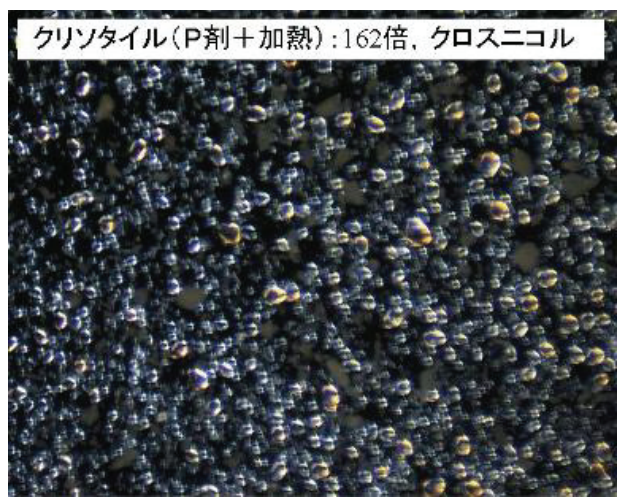

透過照明(クロスニコル)：P剂十加熱

写真-16 偏光判定法によるアスベストの検出(クリソタイル)

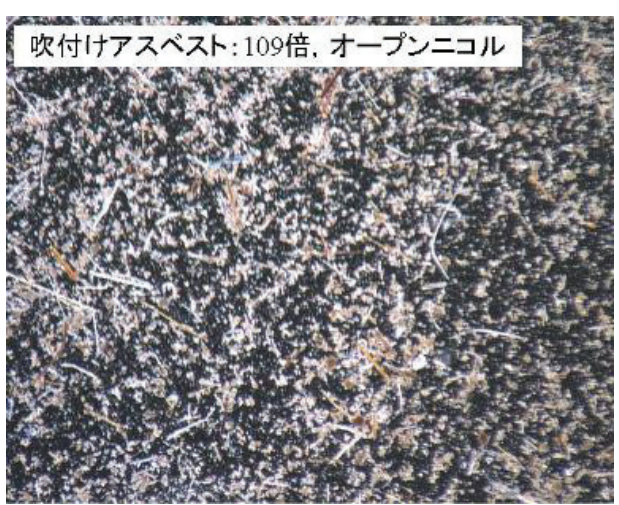

落射照明十透過照明（オープンニコル）

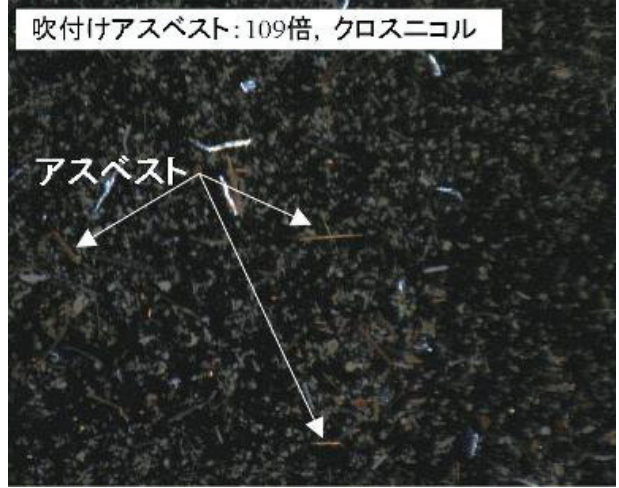

透過照明(クロスニコル)

写真-17 偏光判定法によるアスベストの検出(仙台某駐車場吹付けアスベスト処理後)

うな基本的特性を応用し，クロスニコル透過暗視野照明 と落射暗視野照明を交互に行う装置によって観察を行う と，アスベストは常に輝いて観察されるので識別が容易 になる．さらに，アスベストは光学的二軸性を示寸ので, 試料の方向を変化させると消光現象が観察されることを 確認して，上記判断を補強することができる.

本実験で用いた装置は試料に照射する光の方向を変化 させる際，試料プレパラートを固定し，クロスニコル光 学系を回転させる構造のため, 観察が容易であるととも に広範囲を同一条件で同時に観察し, 迅速な判定を行う ことができる.この装置を用いて，クリソタイル，クロ シドライト，アモサイトの標準試料および仙台市某駐車 場の吹付けアスベスト（クロシドライト $24 \%$, クリソタ イル3\%含有）の観察を行った．その観察結果を写真-15 に示寸.

写真-15より，いずれの写真もクロスニコルの状態で 鮮明に輝いており，この状態から試料の方向を変化させ ると消光現象が観察された。 したがって，アスベストの 種別を特定することまでは熟練者でないと難しいものの アスベスト共通の性質が認められるため, その存在が確 認された.
次に, 前述のアスベスト標準試料に薬液を加えて $700^{\circ} \mathrm{C}$ で加熱してできた焼成物についても，この装置で 偏光判定を行ったが，いずれのケースもクロスニコル状 態では繊維状結晶の輝きは見られず，アスベストの特性 は観察できなかった，その一例として，クリソタイルに R剤およびP剤を添加して $700^{\circ} \mathrm{C} て ゙ 1$ 時間加熱した試料の 結果を写真-16に示す，焼成物が粒状の形状をしている ことが分かるとともに，アスベストを表寸筋状の光沢物 は発見できない。

また，仙台市某駐車場の吹付けアスベストのR剂散布 後に加熱処理した試料の写真を写真-17に示寸. 写真に 示すように仙台市某駐車場の吹付けアスベストについて は, 最初の加熱実験で得られた焼成物からは, クロスニ コル状態ではっきりとアスベストを示す繊維状結晶が残 っていることが確認できる．また，薬液を追加添加して 加熱溶融した焼成物からは繊維状結晶が消失していた.

したがって, 前述のSEM観察やX線回折分析と同様の 判定となる結果が得られた.

これらの結果から，溶融や融解などの処理をした後の アスベストの有無については，この偏光判定法を用いた 簡易装置でも十分に確認できることが検証できた. 


\section{7. まとめ}

本研究では，吹付けアスベストの工事に伴う廃棄物の 処理に関して，除去および封じ込め工事で使用されてい るカルシウム化合物を主成分とする薬液を含浸させるこ とにより， $700^{\circ} \mathrm{C}$ 低温加熱でアスベストの無害化（非 䋊維化，非石綿化）の可能性を検討した.さらに，今後 膨大な量の排出が予想されているアスベスト成形板につ いても検討した．本研究の範囲で得られた結果をまとめ ると以下の通りである.

（1）アスベストを $1,000^{\circ} \mathrm{C}$ で2時間加熱して，その変化 を走査型電子顕微鏡で観察した. クリソタイルお よびアモサイトは針状繊維形態を保持しており, 融点が若干低いクロシドライトは一部溶融してい るが完全な非石綿化とは言えない状態であった。 アスベストは加熱すると脆くはなるが，この程度 の温度では完全な無害化はできないことがわかっ た.

(2) 実際のアスベスト工事で用いるカルシウム化合物 を主成分とする薬液をアスベスト標準試料に添加 して, $700^{\circ} \mathrm{C}$ の温度で2時間加熱した場合と 1 時間加 熱した場合の変化をSEM観察により比較した。 ど ちらの場合も，アスベストは特有の針状組織が完 全に崩れ，ほとんど同様の融解状態を呈していた。 これより加熱分解は， $700^{\circ} \mathrm{Cで} 1$ 時間で行えること がわかった．また，加熱生成物は，結晶水を含む 鉱物もあり，潮解性を示した。

(3) アスベスト使用量の多くをクリソタイルが占める ため, アスベスト処理に関してはクリソタイルを 試料として研究していることが多い. クロシドラ イトやアモサイトについても加熱分解を行った結 果, クリソタイルより簡単に分解するため, アス ベスト含有物の加熱処理を研究する上では，融点 が最も高いクリソタイルを試料として選んで問題 はないと思われる.

(4) クリソタイルとセメントの配合比を変えた 2 種類 の試料を使って，アスベスト以外の混入物がある 場合の効果を検証した. アスベスト䋊維の周囲を 異物が覆うため，加熱条件を調整すべきかと懸念 されたが，同条件 $\left(700^{\circ} \mathrm{C}\right.$ で1時間）で溶融し無害 化が可能であった.

(5) SEMによる観察により，形態的に無害化（非繊維 化，非石綿化）が確認できたが，成分としての変 化を検証するため，粉末X線回折により分析した. 薬液を添加して所定の加熱処理を施した試料からは, アスベストの成分を示す特有のピークが認められず, 他の成分に変化していることが確認できた.
（6）工事現場から実際に封じ込め工事を施したアスベ スト含有試料を採取して，標準試料を用いた加熱 実験と同様の条件 $\left(700^{\circ} \mathrm{C} 1\right.$ 時間）で加熱溶融した が，結果的にはX線回折分析において，アスベス トの残存が確認された. 封じ込め工事用の薬液だ けでは700 $\mathrm{C}$ 1時間の低温溶融での無害化は難しい 吹付けアスベストに同重量の除去用薬液を添加し て，再度同じ条件で加熱溶融したところ，SEM観 察およびX線回折分析いずれにおいても残存は認 められなかつた.

(7) 実際のアスベストの溶融処理において，無害化を 確認する手段として，SEMやX線回折を使用する のは煩雑である. そのため, ポータブルタイプの 偏光判定装置との比較を行った. その結果, 偏光 判定装置を用いて，消光現象を確認することで SEMやX線回折分析と同様にアスベストの存在が 判定できた。

(8) アスベスト成形板についても，スレート板を粉砕 し，薬液を浸潤させて，吹付けアスベストと同様 の条件で加熱溶融した，その結果，アスベストの 針状組織が消失しており，スレート板についても 低温融解による無害化は可能であることがわかっ た.

(9) 現場の吹付けアスベストやアスベスト成形板に対 しても，カルシウム化合物を主成分とする薬液を 添加あるいは含浸させることにより，低温溶融に よる無害化が可能であることがわかった.

アスベスト含有廃革物の低温溶融を可能にするには, 今後，次のような課題を解決する必要がある.

（1）現場工事における薬液の噴霧では，薬液量の不足や むら等が生じ低温溶融による無害化が難しい場合が あるので，アスベスト含有廃棄物の無害化を確実に するためには，薬液の吹き付け状況の確認を容易に 行う方法の確立が必要である.

（2）実際に排出されるアスベスト含有廃棄物は，混入成 分が明らかでないため，加熱処理した際に有害物質 を発生させないような燒却炉の開発が必要である. 本研究では， $700^{\circ} \mathrm{Cを}$ 対象としているが，これは処 理できる最低温度であり，また，ダイオキシン発生 の可能性, 焼却温度のバラツキ等が考えられるため, 実際の溶融処理では，余裕を見て $800^{\circ} \mathrm{C} \sim 900^{\circ} \mathrm{C}$ で行 うことを想定した焼却炉の開発が必要である.

(3) アスベスト成形板については今回の試料は粉砕加工 を施したので薬液が十分浸透しており，期待通りの 結果となったが，実際のサイズは定尺の大型のもの であるので，薬液を十分に浸透させる工夫が必要で ある。 
（4）溶融で発生した焼成物は減容化の効果はあるものの, 安定型処分に適したものであるのか，さらにリサイ クルでの使用に值寸るものなのか，今後の研究が必 要である.

謝辞 : 本研究を遂行するにあたり, 山口大学大学院理工 学研究科環境共生系専攻の喜多英敏教授, 古賀智子非常 勤研究員には，貴重なご意見・ご指導・ご協力を賜りま した. また，山口県産業技術センターの石田浩一専門研 究員には，X線回折分析に関して貴重なご助言を頂きま した.ここに記して感謝の意を表します。

\section{参考文献}

1) 粟野仁雄 : アスベスト禍, 集英社新書, 2006.

2) 中地重晴 : アスベスト対策とリスクコミュニケーション, 資源環境対策，Vol.41,No.12,pp.42-47,2005.

3) 萩原博之：拡散するアスベスト被害, 日経ものづくり, 2005年 8 月号, No.611,pp.97-104, 2005.

4) 工藤光弘 : 石綿に関わる労衝衛生管理上の知見について, 働く人の安全と健康, Vol.6,No.6,pp.23-29,2005.

5) 道路施設アスベスト対策検討委員会 : 道路施設におけるア スベスト対策について報告書，2005.

6) 国土交通省アスベスト対策推進本部：国土交通省における アスベスト対策の推進，2006.

7) 藤重昌生，小島 昭，佐藤良太 : 低温分解によるアスベス卜 の非石綿化および非䋊維化，資源環境対策，Vol.41，No.14， pp.78-82,2005.

8）小島 昭，藤重昌生 : アスベストの低温分解による非繊維化 および非石綿化，金属，Vol.76,No.2,pp.167-173,2006.

9) 小島 昭, 藤重昌生, 佐藤良太 : フロン分解物を用いたクリ ソタイルアスベストの熱分解温度の低温化，材料の科学と 工学, Vol.42,No.2,pp.41-46,2005.

10)小島 昭, 藤重昌生, 佐藤良太 : フロン分解物を利用したア
スベストの低温分解による無害化，産業と環境，Vol.34 No.12,pp.50-52,2005.

11) 小島 昭, 藤重昌生, 細谷静，小淵秀樹，佐藤良太 : フロン 分解物を用いたクリソタイルアスベストの分解における最 適条件，材料の科学と工学, Vol.43,No.1,pp.43-48, 2006.

12)藤重昌生，小淵秀樹，佐藤良太，小島 昭 : 塩を用いた吹付 けアスベスト中のクリソタイルの低温分解, 日本セラミッ クス協会学術論文誌, Vol.114,No.4,pp.355-358,2006.

13) 小島 昭，藤重昌生 : 塩を用いるアスベストの低温分解，月 刊エコインダストリー, Vol.11,No.6,pp.27-31,2006.

14) 小島 昭, 藤重昌生 : 塩を添加寸ることによるクリソタイル の熱分解温度の低温化，セラミックス, Vol.41, No.10, pp.847850, 2006.

15)小島 昭, 藤重昌生 : アスベストの非䋊維化および非石綿化, 機能材料, Vol.26, No.10,pp.5-10,2006.

16)藤重昌生，小島 昭 : アスベス卜無害化処理技術の研究事例 と今後の可能性，資源環境対策，Vol.43,No.3,pp.104-108, 2007.

17)小島 昭，藤重昌生 : アスベストの分解技術，ケミカル・エ ンジニヤリング, Vol.51,No.2,pp.161-167,2006.

18)滝澤行雄 : アスベストによる環境污染と健康障害，資源環 境対策，Vol.41,No.12,pp.30-41,2005.

19)大場 茂, 矢野重信 : X 線構造解析（化学者のための基礎講 座），朝倉書店，1999.

20)山路功：X 線回折法によるアスベストの分析，資源環境対 策, Vol.41,No.14,pp.97-101,2005.

21)関口晴男 : X 線回折法によるアスベストの定量分析，島津 評論, Vol.55, pp.77-81, 1998.

22)橋本忍，山口明良 : アスベストの機械的粉砕とその焼結性, 日本セラミックス協会学術論文誌，Vol.113,pp.312-316,2005.

23)橋本忍, 山口明良, 本多沢雄, 淡路英夫, 福田功一郎 : ア スベスト含有セメント板中のアスベストの機械的粉砕，日 本セラミックス協会学術論文誌, Vol.113,pp.804-807,2005.

\section{TREATMENT OF ASBESTOS-CONTAINING WASTE BY LOW-TEMPERATURE HEATING}

\section{Hidehiro UCHINO, Kajiro SAKAMOTO, Yoichi FUNAI, Hideaki NAKAMURA and Ayaho MIYAMOTO}

The health hazard caused by asbestos has become a serious social issue, and the thoroughness in prevention measures of scattering asbestos becomes an important problem. In this paper, it is attempted to develop a procedure that asbestos can be transformed into non-fiber and non-asbestos by means of heating with the agent for removal or encapsulation of asbestos. As a result, asbestos is made to non-fiber and non-asbestos by heating at $700^{\circ} \mathrm{C}$ for one hour with the calcium-containing agent. Also the sprayed asbestos and the asbestos-containing cement board can be non-fiber and non-asbestos at the same temperature and time period. 